\author{
Jun/2019 \\ Working Paper 19-14 \\ rcea.org/RePEc/pdf/wp19-14.pdf
}

\title{
If You Think 9-Ending Prices ARe LoW, THINK AgaIN
}

\author{
Avichai Snir \\ Netanya Academic College, Israel \\ Daniel Levy \\ Bar-Ilan University, Israel \\ Emory University, USA \\ RCEA
}

Copyright belongs to the author. Short sections of the text, not exceeding three paragraphs, can be used provided proper acknowledgement is given.

The Rimini Centre for Economic Analysis (RCEA) was established in March 2007. RCEA is a private, nonprofit organization dedicated to independent research in Applied and Theoretical Economics and related fields. RCEA organizes seminars and workshops, sponsors a general interest journal, the Review of Economic Analysis (REA), and organizes a biennial conference, the Rimini Conference in Economics and Finance (RCEF). Scientific work contributed by the RCEA Scholars is published in the RCEA Working Paper series.

The views expressed in this paper are those of the authors. No responsibility for them should be attributed to the Rimini Centre for Economic Analysis. 


\title{
If You Think 9-Ending Prices Are Low, Think Again*
}

\author{
Avichai Snir \\ Department of Banking and Finance \\ Netanya Academic College \\ Netanya 42365, ISRAEL \\ Avichai.Snir@gmail.com
}

\author{
Daniel Levy** \\ Department of Economics \\ Bar-Ilan University \\ Ramat-Gan 52900, ISRAEL, \\ Department of Economics \\ Emory University \\ Atlanta, GA 30322, USA, and \\ Rimini Center for Economic Analysis, ITALY \\ Daniel.Levy@biu.ac.il
}

June 8, 2019

JEL Codes: M30, M31, L11, L16, L81, D12, D22, D40, D90, D91, E31

Key Words: Behavioral Pricing, Psychological Prices, Price Perception, Image Effect, 9-Ending Prices, Price Points, Regular Prices, Sale Prices

* We thank Haipeng Allan Chen for his encouragement and advice during the manuscript preparation process. Jens Mehrhoff kindly answered our questions about the data. Tim Ginker was very helpful in answering our questions on data processing and the econometric analyses. The usual disclaimer applies.

** Corresponding author: Daniel.Levy@biu.ac.il,Tel: +972-3-5318331, Fax: +972-3-7384034 


\title{
If You Think 9-Ending Prices Are Low, Think Again
}

\begin{abstract}
9-ending prices are a dominant feature of many retail settings, which according to the existing literature, is because consumers perceive them as being relatively low. Are 9ending prices really lower than comparable non 9-ending prices? Surprisingly, the empirical evidence on this question is scarce. We use 8 years of weekly scanner price data with over 98 million price observations to document four findings. First, at the category level, 9-ending prices are usually higher, on average, than non 9-ending prices. Second, at the product level, in most cases, 9-ending prices are, on average, higher than prices with other endings. Third, sale prices are more likely to be non- 9 ending than the corresponding regular prices. Fourth, among sale prices, 9-ending prices are often lower, on average, than comparable non 9-ending prices. The first three findings imply that although consumers may associate 9-ending prices with low prices, the data indicates otherwise. The fourth finding offers a possible explanation for this misperception. Retailers may be using 9ending prices to draw consumers' attention to particularly large price cuts during sales, which perhaps conditions the shoppers to associate 9-ending prices with low prices.
\end{abstract}

JEL Codes: M30, M31, L11, L16, L81, D12, D22, D40, D90, D91, E31

Key Words: Behavioral Pricing, Psychological Prices, Price Perception, Image Effect, 9-Ending Prices, Price Points, Regular Prices, Sale Prices 


\section{Introduction}

Dozens of studies demonstrate that 9-ending prices comprise as much as 60\%-95\% of many retail prices, which is significantly greater than $10 \%$ that we would expect based on purely random (uniform) distribution. The effect of 9-ending prices on consumer demand and on sales volume in many retail settings, is also well-documented and widely recognized. One of the key conclusions that these studies reach is that shoppers tend to perceive 9-ending prices as lower than comparable non 9-ending prices. ${ }^{1}$

In this paper, we ask whether this perception is justified. That is, are 9-ending prices really lower than non 9-ending prices? This is a fundamental question in the context of the literature on behavioral pricing, in light of the overwhelming popularity of 9-ending prices, and the widespread belief that 9-ending prices are lower than comparable non 9ending prices.

Surprisingly, however, the empirical studies that directly address this question are scarce. Schindler (2001) is a rare exception. During a two-month period in 1997, he collected at a major US metropolitan area, comparable retail price data for 120 brandname general merchandise goods. Each good he sampled was specified precisely in terms of its attributes, such as the brand and the model number, the package size, etc. For each good, Schindler collected 10 prices from 10 different retailers (forming comparison price sets), yielding a total of 1,200 price observations. In total, his price sample covered 65 different retailers, including department stores, discount stores, specialty stores, drug stores, supermarkets, automotive supply stores, etc.

Schindler (2001) found that counter to the common popular belief, 99-ending prices were less likely to be the lowest in their comparison set. For example, he found that the average 99-ending price was $24.1 \%$ higher than the lowest price for the item in the comparison set.

In this paper, we revisit the question, but unlike Schindler (2001), who focuses his analyses only on 99-ending prices, we focus on 9-ending prices (99-ending prices are a

\footnotetext{
${ }^{1}$ See, for example, Anderson et al (2015), Anderson and Simester (2003a, 2003b, 2009), Ater and Gerlitz (2017), Bader and Weinland (1932), Bhattacharya, et al (2012), Blinder et al (1998), Carver and Padgett (2012), Choi et al (2012), Gedenk and Sattler (1999), Gendall, et al (1998), Ginzberg (1936), Hackl et al (2014), Jeong and Crompton (2018), Kalyanam and Shively (1998), Kashyap (1995), Klenow and Malin (2011), Knotek (2019), Kreul (1982), Lee et al (2009), Levy et al (2011, 2019), Macé (2012), Manning and Sprott (2009), Mathä (2009), Freling et al (2010), Ngobo et al (2010), Quigley and Notarantonio (1992), Ruffle and Shtudiner (2006), Schindler (1984, 1991, 2001, 2006), Schindler and Kibarian (1993, 1996), Schindler and Kirby (1997), Schindler and Warren (1988), Shlain (2018), Snir et al (2017), Stiving and Winer (1997), Thomas and Morwitz (2005, 2009), and Twedt (1965).
} 
subset of 9-ending prices). For our analyses, we use a retail scanner price dataset from a major Midwestern US supermarket chain.

The data has numerous advantages. First, it is large, containing over 98 million weekly price observations. Second, it includes the prices of over 18,000 different products. Third, the prices are the actual transaction prices, as recorded by the scanners at the cash registers. Fourth, the data set is weekly, which corresponds to the common retail practice of weekly pricing and price adjustment cycle.

To assess whether or not 9-ending prices are indeed lower relative to comparable non 9-ending prices, we follow Schindler (2001) by running the same tests that he run. That makes it possible to compare our findings for 9-ending prices to his findings for 99-ending prices.

The sheer size of our dataset, however, enables us to go beyond Schindler's tests as follows. First, we are able to conduct the analysis at the category level, for each one of the 29 product categories in the data. Second, the panel structure of the dataset enables us to compare prices across stores, within stores, and over time. We take advantage of these possibilities by estimating regression equations with fixed effects that control for stores, product sub-categories, weeks, and products.

This allows us to measure the differences between 9-ending and non 9-ending prices, while we control for the variability across stores, for sub-category level inflation, and for products within stores. The differences that we report, are therefore the residual price differences that remain within stores between similar goods on the same week, and for each product in each store over time.

Our findings are as follows. First, we find that at the category level, 9-ending prices are on average higher than non 9-ending prices. Second, at the product level, we find that in most cases, 9-ending prices are on average higher than prices with other endings. Third, we find that sale prices are more likely to be non-9 ending than the corresponding regular prices. Fourth, we find that among sale prices, 9-ending prices are often lower, on average, than comparable non 9-ending prices.

We run several robustness tests, which include a comparison of 9-ending prices to 0ending prices, considering the effect of 9 as the highest possible right-most digit, using price level (instead of log-transformed prices), excluding the outlier observations, and using a sale filter to identify sale prices. The findings we report are robust to these tests.

Based on the first three findings, we conclude that although consumers may associate 
9-ending prices with low prices, our data indicates otherwise. The fourth finding offers a possible explanation for why 9-ending prices are perceived by consumers as low. The retailers appear to use 9-ending prices to emphasize large price cuts during sales, which may be guiding the shoppers towards associating 9-ending prices with low prices.

The paper is organized as follows. In section 2, we describe the data. In section 3, we discuss some descriptive statistics, and offer evidence on the frequency distribution of the last digit in our price data. In section 4, we present the results of several statistical and econometric analyses to determine whether or not 9-ending prices are lower than comparable non 9-ending prices. In section 5, we present the results of robustness tests. We conclude in section 6 by summarizing the main findings, and discussing ethical aspects of the implications.

\section{Retail Scanner Price Data}

We study price data from a large US Midwestern retail supermarket chain Dominick's Finer Food. We have price data from the chain's 93 stores, containing 98,914,300 weekly price observations for 18,036 different products in 29 product categories, during the 8-year period from September 14, 1989 to May 14, 1997 (Mehrhoff, 2018). ${ }^{2}$ These are actual transaction prices that consumers have paid each week, as recorded by the chain's scanners at the checkout cash registers. ${ }^{3}$ The products in our sample make up about $30 \%$ of the chain's revenue. ${ }^{4}$

\section{Descriptive Statistics and the Distribution of the Last Digit}

Table 1 offers descriptive statistics about the price data, by product categories. Among the 29 product categories, the smallest category in terms of the total number of observations we have, Bath Soaps, has 418,097 weekly price observations, and the largest, Soft Drinks, has 10,741,742 weekly price observations. In terms of the number of

\footnotetext{
${ }^{2}$ For statistical analyses, we identify the products by their SKU (Stock Keeping Unit) number.

${ }^{3}$ For more details about Dominick's data, see for example, Barsky, et al. (2003), Chen, et al. (2008), Chevalier, et al. (2003), and Levy et al. (2010). Dominick's data can be downloaded from the University of Chicago Business School's web site: https://www.chicagobooth.edu/research/kilts/datasets/dominicks. For Dominick's code manual and user guide, see: https://www.chicagobooth.edu/-/media/enterprise/centers/kilts/ datasets/dominicks-dataset/dominicks-manual-and-codebook_kiltscenter.aspx, accessed May 6, 2019. ${ }^{4}$ Dominick's data have been used in dozens of studies. Recent examples include Tsiros and Hardesty (2010), Meza and Sudhir (2010), Chahrour (2011), Midrigan (2011), Eichenbaum et al (2011), Macé (2012), Guimaraes and Sheedy (2011), etc. See: https://www.chicagobooth.edu/research/kilts/datasets/dominicks\# for a complete list.
} 
products, the Oatmeal category is the smallest, containing 96 different products, and Shampoos category is the largest, containing 2,930 different products. The average price in the data is $\$ 2.59$.

The frequency distribution of the last digit in the entire dataset for all categories combined is shown in Figure 1. According to the figure, 9 is the most frequent price ending comprising $63.9 \%$ of the prices, followed by 5-endings, comprising $11.4 \%$ of the prices, and 0 -endings, comprising $4.7 \%$ of the prices. The remaining endings are less common, each comprising between $1.9 \%-4.1 \%$ of the prices.

The frequency distribution of the last digit by product category is shown in Figure 2. According to the plots in the figure, 9 is the most frequent price ending in 28 out of the 29 categories, with the exception of the category of Cigarettes, which according to Besley and Rosen (1999) and Chen et al (2008), is subject to numerous regulatory restrictions. In some product categories, 9-endingss are particularly dominant, comprising over $80 \%$ of the prices. These include Analgesics (86.0\%), Bath Soap (88.3\%), Beer (95.7\%), Grooming Products (86.8\%), Shampoos (91.5\%) and Soft Drinks (82.7\%).

\section{Results of the Econometric Analyses}

\subsection{Average 9-Ending and Non 9-Ending Prices}

As a first check of whether or not 9-ending prices are indeed lower than non 9-ending prices, we compare the averages of 9-ending and non-9 ending prices in each category. If consumers believe that 9-ending prices are lower than other prices because this is the pattern that they observe in the marketplace, then we would expect that, on average, 9ending prices will be lower than prices that end with other digits.

We report the results of this analysis in Table 2. In column (1) of the table, we report the average 9-ending prices, in column (2) we report the average non 9-ending prices, and in column (3) we report the percentage difference between the average 9-ending and non 9-ending prices, computed as a log-difference.

We find that in 22 out of the 29 product categories, the average 9-ending prices exceed the corresponding average non 9-ending prices. In some product categories, the size of this difference is particularly large. In 10 product categories, the average 9-ending prices are higher than the average non 9-ending prices by $20 \%$ or more. These categories are Analgesics (21.24\%), Cigarettes (55.48\%), Front-End-Candies (33.38\%), Grooming Products (22.15\%), Paper Towels (26.24\%), Soft Drinks (56.36\%), Shampoos (20.66\%), 
Soaps (25.65\%), Tuna (19.96\%), and Toilet Papers (42.56\%). The average percentage difference computed across the 22 product categories in which the average 9-ending prices exceed the corresponding average non 9-ending prices is $18 \%$.

Thus, overall, the differences we find between the average 9-ending and average non 9-ending prices are consistent with Schindler's (2001) findings for 99-ending prices: 9ending prices are on average higher than non 9-ending prices, which is counter to the popular belief.

\subsection{A Comparison of 9-Ending and Non 9-Ending Prices for Individual Products at the} Store Level

It could be that the stores that have higher than average prices also have higher than average shares of 9-ending prices. In that case, even if 9-ending prices are the lowest within each store, we might still find that across all stores 9-ending prices are higher than the corresponding non-9 ending prices.

In addition, some of Dominick's product categories include several sub-categories. If 9-ending prices are more prevalent in sub-categories with relatively high prices than in sub-categories with lower prices, then even if 9-ending prices are the lowest within each sub-category, we might still find the opposite at the category level.

To explore these possibilities, we calculate for each product at each store, the percentage difference between the average 9-ending and non 9-ending prices. We use the resulting figures to plot category-level histograms, which show the frequency distribution of these percentage differences. Figure 3 depicts the resulting frequency distributions for each of Dominick’s 29 product categories. In Table 3, we report the corresponding descriptive statistics. These statistics include the median, the average, the standard deviation, the skewness, and the kurtosis for each product category.

Inspecting the plots in Figure 3 and the corresponding descriptive statistics in Table 3, we see that at the product-store level, in 25 of the 29 product categories, the average of the percentage difference is positive. Thus, in vast majority of categories, the average 9ending prices are higher than the average non 9-ending prices even when we look at the level of a specific product, at a specific store.

We can also see that in 26 of the 29 product categories, the median of the percentage difference is positive, suggesting that the higher average 9-ending prices are not caused by outliers. Rather 9-ending prices are higher on average because more product-stores have 
higher average 9-ending than average non 9-ending prices.

According to Table 3, the skewness is positive in 18 of the 29 product categories, which means that in these product categories, the distribution of the percentage difference is skewed to the right. Therefore, in addition to the finding that in most categories there are more product-stores with higher average 9-ending than average non 9-ending prices, we also find a longer tail on the right-hand side of the distribution. In other words, in these categories, we also find more extreme cases where the average 9-ending price is much higher than the average non 9-ending price than cases where the average 9-ending price is much lower than the average non 9-ending price.

According to Table 3, the values of the kurtosis statistic are all greater than 3, meaning that the tails of the distributions of the percentage gap are thicker in comparison to the Normal Distribution, in all 29 product categories. Importantly, the kurtosis attains particularly high values in cases where the skewness is positive and large. Indeed, the correlation between the measures of skewness and kurtosis in this data is 0.91, exceptionally high.

We thus rule out the possibility that 9-ending prices are lower than non 9-ending prices at the level of individual stores or within sub-categories.

\subsection{The Role of the Upward Trend in the Prevalence of 9-Ending Prices}

Because prices tend to increase over time, if 9-ending prices became more prevalent over time, then that could lead to high average 9-ending prices overall even if 9-ending prices are lower than non 9-ending prices in any given individual year.

To explore this possibility, we calculate the share of 9-ending prices for each year in the data set from 1989 to 1997. In Table 4, we present the results. The figures in the table suggest that the share of 9-ending prices had increased gradually over time from $51.9 \%$ and 54.7\% in 1989 and 1990, respectively, to 68.9\% and 73.0\% in 1996 and 1997, respectively. Thus, given that US inflation during this period was positive, the increase in the share of 9-ending prices over time can perhaps explain why we find for the entire data series that 9-ending prices are higher, on average, than non 9-ending prices.

To formally test whether 9-ending prices are higher or lower on average than non 9ending prices, while controlling for the effect of the time trend, we estimate a series of OLS regressions with fixed effects at the category level. The dependent variable in these regressions is the log of the price. The main independent variable in all the regressions is a 
dummy for 9-ending prices, which equals 1 if the price is 9-ending, and 0 if the price ends with any other digit. The coefficient of the 9-ending price dummy therefore gives the expected percentage difference between 9-ending and non 9-ending prices. We report the estimation results in Table 5.

In column (1) of Table 5, we report the estimation results of a regression, which includes dummies for weeks and for subcategories-store. Thus, we control for the effects of different subcategories at the store level, and for the overall price trend. The results are not substantially different from the findings we reported in Table 2. In 22 out of the 29 product categories, the expected 9-ending prices are higher than the expected non 9ending prices. The differences are statistically significant in 21 of the cases. In 19 of the 21 product categories, the significance level is $1 \%$.

In column (2), we use a stronger test. Here we add subcategories-store-week dummies. Thus, we control for inflation at the subcategory-store level. The 9-ending price dummy should therefore capture the differences between goods that belong to the same subcategory at the same store and on the same week. In other words, the differences that we find between the expected values of the 9-ending and non 9-ending prices, represent the expected differences that exist within a store on a given week between the prices of goods that belong to the same product subcategory.

Using this specification, we find that the expected 9-ending prices are higher than the corresponding expected non 9-ending prices in 23 of the 29 product categories. The differences are statistically significant in 22 of the cases, with 21 of them significant at $1 \%$ level. In one product category, Frozen Dinners, where the expected 9-ending prices are lower than the expected non 9-ending prices, the difference is not statistically significant. In another product category, Oatmeal, where the expected 9-ending prices are lower than the expected non 9-ending prices, the difference is only marginally significant statistically.

Thus, when we add controls for subcategories-store-weeks, we find that the expected 9-ending prices are lower than the expected non 9-ending prices with statistical significance in only 5 of the 29 product categories. In other words, when we consider the store-subcategory level, which is the level that consumers look at when comparing goods within a store, we find that in 24 of the 29 categories, the expected 9-ending prices are either higher, or not statistically different, than the expected non 9-ending prices.

As an additional test, we perform an even more restrictive analysis, by looking at the prices of individual products within individual stores over time and compare the prices 
when each good is sold at 9-ending and at non 9-ending prices. It might be that even if 9ending prices are not necessarily the lowest within each sub-category, they still represent a good purchase opportunity because they are associated with times when individual goods are offered at low prices.

In column (3), we report the estimation results of this test. The independent variables are the dummy for 9-ending prices, fixed effects for products at the store-level, and for weeks. Here we find that in 26 out of the 29 product categories, the expected 9-ending prices are still higher than corresponding non 9-ending prices. Thus, even for individual goods at individual stores, in almost all product categories, 9-ending prices are expected to be higher than non 9-ending prices.

\subsection{Regular Prices vs. Sale Prices}

Existing studies suggest that consumers perceive 9-ending prices as low because they tend to associate 9-endings with sale prices (see, for example, Schindler and Kibarian, 2001). However, Levy et al. (2019) report that in Dominick's dataset, 9-ending prices are more common among regular prices than among sale prices. In other words, Levy et al (2019), analyzing the same dataset as we do here, find that regular prices are more likely to be 9-ending than sale prices.

In Table 6, we show that this result holds true also when we consider the proportion of 9-ending prices in regular and sale prices, at the category level. To identify sale-prices, we use a sale dummy ("sale flag”), which is included in the Dominick’s dataset. This sale indicator variable, however, has a disadvantage, because according to Peltzman (2000) and Dominick's Data Manual, the sale dummy was not set by Dominick's on a regular basis, and consequently there are instances were a good was offered at a sale price, but the Dominick's sale dummy indicates no sale price. An alternative to the use of the sales dummy would be to use a sale filter, a mechanical algorithm that identifies sale prices (Dutta et al 2002, Levy et al 2002, Nakamura and Steinsson 2008). We employ this alternative method below as a robustness test in section 5.5.

The figures reported in column (1) of Table 6 show the percentage of sale prices that are 9-ending. Column (2) reports the percentage of regular prices (the prices that are not flagged by the sale dummy) that are 9-ending. Column (3) reports the difference between the shares of 9-ending prices among sale and regular prices.

We find that in 25 out of the 29 product categories (the categories of Cereals, 
Cigarettes, Frozen Juices, and Toothpastes being the exception), the values in column (3) are negative, with an average of $-18.5 \%$. In other words, in these categories, 9-ending prices are more common among regular prices than among sale prices. Furthermore, in the Cigarettes category, there are only 21 observations that Dominick’s sale dummy marks as sale prices, and thus the results in that category are based on a very small sample of sale prices. Therefore, consumers' tendency to associate 9-endings with low prices cannot be explained by 9-ending prices being sale prices. That is because the shoppers are more likely to encounter 9-ending prices when they buy the goods at a regular price than at a sale price.

There is another possibility, however. Even if 9-endings are not more common among sale prices than among regular prices, the belief of the consumers that 9-ending prices are low, could perhaps still be rationalized. If 9-ending prices are lower on average than non-9 ending prices among sale prices, then it is possible that consumers associate 9-endings with price cuts. Indeed, Schindler (2001) offers this as a possible explanation for his finding that 99-ending prices are not as low as is commonly believed.

To explore this possibility, we run the same OLS regressions with the same fixed effects, as the ones we presented in Table 4. The only exception is that we now estimate separate regressions for regular prices and for sale prices. We report the estimation results in Table 7. The figures that we report in the table are the coefficient estimates of the 9ending price dummy, which equals 1 if the price ends with 9, and 0 if the price ends with any other digit.

In columns (1)-(3) of the table, we report the estimation results for regular prices, and in columns (4)-(6) for sale prices. In columns (1) and (4), we report the estimation results of regressions where we include controls for weeks and for subcategories-store. In columns (2) and (5), we report the estimation results of regressions that include controls for subcategories- store-weeks. In columns (3) and (6), we report the estimation results of the regressions that include controls for weeks and for products-store.

For regular prices, the estimation results in column (1) suggest that the expected 9ending prices are lower than the expected non 9-ending prices (that is, the estimated coefficient is negative and statistically significant) in 10 product categories. In one category (Toothpastes), however, the difference is only marginally significant. In column (2), the coefficient of the 9-ending dummy in the regression for the Toothpastes' category is not significant and, consequently, the expected 9-ending prices are lower than the 
expected non 9-ending prices in 9 product categories.

In column (3), where we use dummies for products-store, we find that the expected 9ending prices are lower than the expected non 9-ending prices in only four product categories. Thus, when we focus on regular prices, and include dummies for products in specific stores, we find that in 24 out of 29 product categories, the expected 9-ending prices are higher than the expected non 9-ending prices, and in one category, there are no statistically significant differences between 9-ending and non 9-ending prices.

For sale prices, we cannot estimate the regressions for the Cigarettes' category because the Dominick's sale dummy identifies only 21 prices as sale prices and all of them are 9ending. For the remaining 28 categories, we find in column (4) that the expected 9-ending prices are lower than the expected non 9-ending prices in 13 product categories, higher in 14 product categories, and there is no statistically significant difference in one product category. According to the figures in column (5), the expected 9-ending prices are lower than the expected non 9-ending prices in 10 product categories, higher in 12 categories, and there are no statistically significant differences in six product categories.

In column (6), where we use dummies for products-store, we find that the expected 9ending prices are lower than the expected non 9-ending prices in 17 categories, higher in 9 product categories, and there are no statistically significant differences in two categories.

Thus, to summarize the results on regular and sale prices, we find that for regular prices, which in our data are the bulk of the prices (82.2\%), 9-endings are not indicative of a better deal than non 9-ending prices. For sale prices, the results are more mixed. At least according to column (6), which focuses on the difference between 9- and non 9-ending prices of products within stores, in 19 out of 28 product categories, the expected 9-ending prices are either lower or not higher than the expected non 9-ending prices.

This suggests that although 9-ending prices are in general higher, not lower, than non 9-ending prices, it might be that Dominick's helps to maintain the image of 9-ending prices as low prices by setting sale prices at 9-endings in the case of price cuts. Such behavior by the retailer can perhaps explain how consumers learn to associate 9-endings with low prices.

\section{Robustness Tests}

To assess the robustness of our findings, we run several additional tests which we present below as follows. In section 5.1, we compare 9-ending prices to 0 -ending prices. 
In section 5.2, we explore the effect of 9 as the highest possible right-most digit. In section 5.3, we assess the effect of the log-transformation of prices by redoing the analyses using the level of prices. In section 5.4, we rerun the analyses by excluding outlier observations. Finally, in section 5.5, we compare again regular and sale prices, but this time using a sale filter.

\subsection{A Comparison of 9-Ending and 0-Ending Prices}

It is often argued that consumers interpret 9-ending prices as if they come with a small gain relative to the nearby round price (Schindler and Kirby, 1997). In addition, it has been suggested that 9-endings signal low prices, whereas 0-endings signal quality (Schindler and Kirby 1997, Stiving and Winer 1997, Stiving 2000, Schindler and Kibarian 2001, Schindler 2006). It is therefore possible that the low-price image that 9-ending prices have, stems from consumers' practice of interpreting 9-ending prices relative to, or in comparison to, the nearby 0-ending prices, and judging them accordingly. Schindler (2001) examines this hypothesis by comparing 99-ending prices to 00-ending prices.

We explore this hypothesis with our data by repeating the analyses that we report in Tables 2 and 5. This time, however, we compare 9-ending prices to 0-ending prices only, excluding from our analyses all other non 9-ending prices. In Table 8, which is equivalent to Table 2, we report for each product category, the average of 9-ending prices in column (1), the average of 0 -ending prices in column (2), and the percentage differences between the two, computed as a log-difference, in column (3).

According to the figures in the table, the average 9-ending prices are higher than the average 0 -ending prices in 20 of the 29 product categories. The average percentage difference computed across these 20 product categories is $10.84 \%$. In some product categories, the size of this difference is particularly large, including Cigarettes (32.54\%), Grooming Products (20.26\%), Soft Drinks (21.84\%), and Toilet Papers (30.63\%).

Thus, even when we restrict the sample of non 9-ending prices to 0-ending prices only, we find that although 0 -endings might be perceived as a signal of quality, in most product categories 0-ending prices are still lower than 9-ending prices, on average.

As a formal test, in Table 9, we report the estimation results of a series of regressions of the differences between 9-ending and 0-ending prices by product categories. These OLS regressions are similar to the ones that we report in Table 5. This time however, the data include only 9-ending and 0-ending prices. 
The estimation results of this regression further strengthen the results we reported in Table 7. In the regression in column (1), which includes dummies for weeks and for subcategories-store, we find that in only five product categories (Bath Soaps, Cookies, Frozen Dinners, Frozen Entrees, and Frozen Juices), the coefficient of 9-ending price dummy is negative and statistically significant. In 21 of the 29 product categories, the coefficient is positive and statistically significant. Thus, the expected 9-ending prices are significantly higher than the expected 0-ending prices in 21 product categories. In three product categories (Crackers, Canned Soup, and Paper Towels), the differences are not statistically significant.

In column (2), where we add fixed effects for subcategory-store-weeks, we find that the coefficient estimate of the 9-ending price dummy is again negative and statistically significant in only five product categories (Bath Soaps, Cookies, Frozen Dinners, Frozen Entrees, and Frozen Juices). The coefficient estimate of the 9-ending price dummy is positive and statistically significant in 20 product categories. Thus, in this specification, we find that the expected 9-ending prices are higher than the expected 0-ending prices in 20 of the 29 product categories. In four product categories (Crackers, Canned Soup, Fabric Softeners, and Paper Towels), the differences are not statistically significant.

In column (3), where we add fixed effects for weeks and for products within stores, we find that the coefficient of the 9-ending price dummy is positive and statistically significant in 21 of the 29 product categories. In other words, we find that even when we restrict the sample to 9 -ending and 0 -ending prices, in 21 of the 29 product categories, a consumer who buys the same good at the same store, is expected to get a better deal if the price s/he pays ends with a 0 than with a 9 . This finding is consistent with Schindler (2001), who finds that in his data, 99-ending price were not, on average, lower than 00ending prices.

\subsection{Could It Be the Rightmost Digit Effect?}

A possible explanation for the finding that 9-ending prices are higher than the prices that end with other digits, is that the difference might be due to 9 being the largest digit. Thus, it is possible that 9-ending prices are higher, on average, than other prices for a technical reason: A price that ends with 9 is greater than any price with the same left most digits but that ends with any digit between 0 and 8 . That is, 9.99 is higher than all the prices in the range 9.90-9.98. 
To test this possibility, we first truncate all price endings so that the right most digits are now all set equal to 0 . To keep track of the original prices, we use an indicator variable which identifies the prices that were 9-ending prior to the truncation. In column (1) of Table 10, we report the average 9-ending prices after-truncation, in column (2) we report the average non 9-ending prices after-truncation, and in column (3) we report the percentage difference between them, computed as a log-difference.

We find that the truncation decreases, as expected, the differences between the average 9-ending and non 9-ending prices. Yet in 21 product categories, the average 9-ending prices are still higher than the average non 9-ending princes. Even after the truncation, the average percentage difference computed across the 21 product categories in which the average 9-ending prices exceed the corresponding average non 9-ending prices is $17.31 \%$.

In Table 11, we report the estimation results of a series of regressions of the differences between 9-ending and non 9-ending prices by product categories, when we use the truncated data. These are OLS regressions with the same fixed effects as the ones we report in Table 5.

In the regression in column (1), which includes dummies for weeks and for subcategories-store, we find that the coefficient of the 9-ending price dummy is negative and statistically significant in only 8 product categories (Cereal, Cookies, Frozen Dinners, Frozen Juices, Fabric Softeners, Oatmeal, Toothbrushes and Toothpastes). In 16 of the 29 product categories, the coefficient of the 9-ending price dummy is positive and statistically significant. In five categories, the differences are not statistically significant (Bath Soaps, Beer, Bottled Juices, Dish Detergents, and Snack Crackers).

In the regression in column (2), which includes fixed effects for subcategory-storeweeks, we find that the coefficient estimate of the 9-ending price dummy is again negative and statistically significant in 8 product categories (Cereal, Cookies, Frozen Dinners, Frozen Juices, Fabric Softeners, Oatmeal, Toothbrushes and Toothpastes). The coefficient estimate of the 9-ending price dummy is positive and statistically significant in 17 product categories. In four categories, the differences are not statistically significant (Bath Soaps, Bottled Juices, cigarettes, Snack Crackers).

In the regression in column (3), which includes fixed effects for weeks and for products within stores, we find that the coefficient of the 9-ending price dummy is positive and statistically significant in 17 of the 29 product categories. In other words, we find that even after we truncate all prices to have a 0-ending, we find that in 17 of the 29 product 
categories, a consumer who buys the same good at the same store, is expected to get a better deal if the price s/he pays does not end with a 9 .

\subsection{Average 9-Ending and Non 9-Ending Prices in Levels}

In the regression analyses above, we use the log of the prices as the dependent variable. To check that our results do not depend on this transformation, we rerun the same OLS regressions with the same fixed effects that we reported in Table 5, but this time we use the level of the prices rather than their logs. The coefficient estimates we report here, should therefore be interpreted as the expected differences in dollars rather than in percentages. The estimation results are reported in Table 12.

In the regression in column (1), which includes dummies for weeks and for subcategories-store, we find that in 21 out of the 29 product categories, the expected 9ending prices are higher than the expected non 9-ending prices. The differences are statistically significant $(p<0.01)$ in 20 of the cases.

In the regression in column (2), which includes subcategories-store-week dummies, we find that the expected 9-ending prices are higher than the corresponding expected non 9ending prices in 19 of the 29 product categories. In four more product categories (Beer, Cigarettes, Frozen Entrees, Toothbrushes), the differences are not statistically significant. Thus, in 23 of 29 product categories, the expected 9-ending prices are either higher or no different than the expected non 9-ending prices.

In the regression in column (3), which includes fixed effects for weeks and for products at the store-level, we find that in 24 out of the 29 product categories, the expected 9-ending prices are higher than corresponding non 9-ending prices. In only 5 product categories (Beer, Cookies, Frozen Entrees, Frozen Juices, Toothpastes), the expected 9ending prices are lower than the expected non 9-ending prices.

Thus, using the level of the prices instead of their logs, does not change the main conclusion we reported above: in great majority of the product categories, the expected 9ending prices are higher than the expected non 9-ending prices, regardless of the additional controls that we include in the regressions.

\subsection{Analysis of the Data with Outliers Excluded}

As another robustness test, we check whether our results are driven by outlier observations. To explore this possibility, in each category we exclude from the sample the 
observations that are more than 2-standard-deviations away from the category mean. Using the restricted sample, we rerun the analyses we reported in Tables 2 and 5.

In columns (1) and (2) of Table 13, we report the average 9-ending and non 9-ending prices in the restricted sample. In column (3), we report the percentage difference between them, computed as a log-difference. Inspecting the figures in the table, we find that the exclusion of the outlier observations does not change the main finding we reported for the entire sample: in 22 product categories, 9-ending prices are on average higher than non 9ending princes. The average percentage difference computed across these 22 product categories is $16 \%$.

In Table 14, we report the estimation results of a series of regressions of the differences between 9-ending and non 9-ending prices by product categories, when the outlier observations are excluded. These are OLS regressions, similar to the regressions we reported in Table 5.

In the regression in column (1), which includes dummies for weeks and for subcategories-store, we find that the coefficient of the 9-ending dummy is negative and statistically significant in 8 product categories (Cereal, Cookies, Frozen Juices, Fabric Softeners, Oatmeal, Snack Crackers, Toothbrushes and Toothpastes). In 19 of the 29 product categories, the coefficient of the 9-ending price dummy is positive and statistically significant. In two categories, the estimated coefficients are not statistically significant (Dish Detergents and Frozen Dinners).

In the regression in column (2), which includes fixed effects for subcategory-storeweeks, we find that the coefficient estimate of the 9-ending price dummy is negative and statistically significant in five product categories (Cereal, Frozen Juices, Fabric Softeners, Toothbrushes and Toothpastes). The coefficient estimate of the 9-ending price dummy is positive and statistically significant in 20 product categories. In four product categories, the estimated coefficients are not statistically significant (Cookies, Frozen Dinners, Oatmeal and Snack Crackers).

In the regression in column (3), which includes fixed effects for weeks and for products within stores, we find that the coefficient of the 9-ending price dummy is negative and statistically significant in 6 product categories (Beer, Cheese, Frozen Juices, Fabric Softeners, Paper Towels, Toothpastes). The coefficient is positive and statistically significant in the remaining 23 of the 29 product categories.

Thus, in comparison to the results we reported for the full sample, when outliers are 
excluded, we still find that the expected 9-ending prices are on average higher than non 9ending prices, in a large majority of the product categories.

\subsection{Regular and Sale Prices Using a Sale Filter}

As a final robustness test, we rerun the regular and sale price analyses as discussed and presented in Tables 6 and 7 in section 4.4. The difference is that this time we identify sale prices by using a sale filter instead of relying on the Dominick's sale dummy, which as noted, might be inaccurate because it may not have been recorded on a regular basis by Dominick's.

Sale filters are mechanical algorithms that identify prices as sale prices if the prices are temporarily reduced. The disadvantage of the sale filters is that they can occasionally lead to false positives, that is, they can wrongly identify a regular price as a sale price (Nakamura and Steinsson 2008, Ray et al 2019). Sale filter also cannot identify sale prices close to the end points. The filters are nevertheless used extensively, because in many datasets, sales indicators are not available.

We use "Filter A" of Nakamura and Steinsson (2008, 2011), which defines a price as a sale price if the price decreased, stayed low for no more than a given number of weeks, and then increased to the pre-sale level or above it. Following Knotek (2019) and Chahrour (2011), we identify a price as a sale price if the price remained low for no more than four weeks.

The figures reported in column (1) of Table 15 show the percentage of sale prices that are 9-ending, when we use a sale filter. Column (2) reports the percentage of 9-ending prices among regular prices, that is, among the prices that are not identified by the sale filter. Column (3) reports the difference between the share of 9-ending prices among sale and regular prices.

In 28 out of the 29 product categories (the category of Frozen Juices being an exception), the figures in column (3) are negative, with an average of $-16.9 \%$. I.e., 9ending prices are more common among regular prices than among sale prices. Therefore, consumers' tendency to associate 9-endings with low prices cannot be explained by 9ending prices being sale prices. That is because they are more likely to encounter 9-ending prices when they buy the goods at a regular price than at a sale price.

As above, we explore the possibility that consumers may associate 9-endings with promotional discounts, by running the same OLS regressions with the same fixed effects, 
as the ones we reported in Table 7. We report the estimation results in Table 16.

For regular prices, the estimation results in columns (1) and (2) suggest that the expected 9-ending prices are lower than the expected non 9-ending prices (that is, the estimated coefficient is negative and statistically significant) in 7 product categories. When we consider sale prices, we find in columns (4) and (5) that the expected 9-ending prices are lower than the expected non 9-ending prices in 10 of the 29 product categories.

When we look at the level of individual goods at individual stores, in columns (3) and (6), we find that for regular prices, column (3), the expected 9-ending prices are significantly lower than the expected non 9-ending prices in 7 out of the 29 product categories. Thus, for regular prices, it appears that even at the level of individual goods, in 22 of the 29 product categories, 9-ending prices are expected to be higher than non 9ending prices.

For sale prices, in column (6), however, the results are more mixed. In 15 out of the 29 product categories, we find that the expected 9-ending prices are significantly lower than the expected non 9-ending prices. In two product categories (Fabric Softeners and Toothbrushes), the differences are not statistically significant, and in one more product category (Frozen Entrees), the expected 9-ending prices is higher than the expected non 9ending price, but the difference is only marginally significant.

Thus, the results we find using the sale filter corroborate the results we find using Dominick's sale dummy. For regular prices, the expected 9-ending prices are usually higher than non 9-ending prices.

When we focus on sale prices only, however, it seems that in many product categories the expected 9-ending prices are lower than the expected non 9-ending prices. Thus, it appears that although overall the expected 9-ending prices are higher than non 9-ending prices, it is possible that 9-ending prices are associated with larger than average price cuts which the retailer is promoting during sales.

\section{Conclusion}

Existing empirical evidence suggests that 9-ending prices are overrepresented in many retail settings, in comparison to the expected frequency based on random, uniform distribution. Studies have also documented non-trivial effects of 9-ending prices on consumer demand and on sales volume. Existing studies conclude that shoppers tend to perceive 9-ending prices as lower than comparable non 9-ending prices. 
In this paper, we ask whether this perception is justified. That is, we ask whether or not 9-ending prices are really lower than comparable non 9-ending prices, using a large retail scanner price dataset, from a major Midwestern US supermarket chain.

We report four findings. First, we find that 9-ending prices are on average higher than non 9-ending prices, at the category level. Second, we find that 9-ending prices are on average higher than non-9-ending prices, at the product level. Third, we find that sale prices are more likely to be non-9 ending than the corresponding regular prices. Fourth, we find that among sale prices, 9-ending prices are often lower, on average, than comparable non 9-ending prices. These findings are robust to variety of sensitivity tests.

First three findings lead us to conclude that the data is inconsistent with the consumers' belief that 9-ending prices are low. To the contrary, we find fairly strong evidence that the average 9-ending price is greater than the average non 9-ending pries, by as much as $18 \%$.

This conclusion raises two related questions, one from the consumers' perspective and the other from the retailers' perspective. From the point of view of the consumers, they seem to believe, mistakenly, that 9-ending prices are low. How is it possible? Over time, it could be argued, consumers would eventually discover that the image of 9-ending prices as low prices is just that, an image, not reality.

We speculate that our fourth finding may offer a possible resolution to this puzzle. In our data, the retailer appears to use 9-ending prices for larger than average price cuts, to highlight, and to draw the shoppers' attention, to price cuts that are particularly large. This practice may be guiding the shoppers towards associating 9-ending prices with low prices.

The second question our findings raise has to do with our retailer's questionable ethical behavior, which emerges from its practice of using 9-ending prices during sales for large price cuts, on the one hand, but simultaneously setting most 9-ending prices higher than non 9-ending prices, on the other. We suspect that this pricing practice is not a coincidence. Rather, it seems to us that the retailer is taking advantage of the 9-ending prices' image in consumers' mind as low prices, by setting more 9-ending prices higher than the non 9-ending prices. Clearly, the retailer is not very transparent here, and its behavior seems ethically questionable.

Recent studies offer evidence that are consistent with this interpretation. Levy et al (2019) report, based on lab experiments and field studies, that consumers use 9-endings as a signal for low prices. Using the same Dominick’s data, along with Israeli retail price 
data, they find that retailers take advantage of the consumers' heuristic processing of 9ending price information, by strategically keeping prices at 9-endings more often after price increases than after price decreases.

Chakraborty et al. (2015) use price data from British supermarkets and report that during their sample period, many individual prices fell but basket prices rose. They conclude, that the frequent small price cuts were used to disguise the basket price increases.

Using data from a US retailer, Anderson, et al. (2017) report that in their data, temporary price cuts and discounts are often offered alongside with regular price increases. They conclude that the retailer they study is trying to mask the regular price increases.

Thus, some retailers deliberately try to disguise their basket price increases by frequent sales and/or small price cuts. Other retailers seem to follow a strategy of "hiding” price increases using a different tactic: they use 9-endings to mask price increases by taking advantage of shoppers' tendency to interpret 9-ending prices as low prices.

These findings are in line with an observation that Akerlof and Shiller (2015, pp. vii, 1) make in describing what they term a phishing equilibrium: “...our free-market system tends to spawn manipulation and deception...if we have some weakness...in the phishing equilibrium someone will take advantage of it.” Following this line of argument, 9-ending pricing can be a fooling-equilibrium where consumers rely on 9-endings as a signal for low prices, and retailers respond by setting 9-ending prices higher than non 9-ending prices, as we document here.

Future studies should explore other and perhaps more recent datasets to see whether the findings we document here for Dominick’s data, also hold for other retailers. Perhaps more importantly, more work along these lines is needed to better understand the reasons for what appears to be consumers' inattentive and perhaps irrational behavior in the way they interpret and understand the retail price data. 


\section{References}

Akerlof, Geroge, and Robert Shiller (2015), Phishing for Phools (Princeton University Press, Princeton, NJ).

Anderson, Eric, Nir Jaimovich, and Duncan Simester (2015), "Price Stickiness: Empirical Evidence of the Menu Cost Channel," Review of Economics and Statistics, 97(4), 813826.

Anderson, Eric, Benjamin Malin, Emi Nakamura, Duncan Simester, and Steinsson, Jón (2017), “Informational Rigidities and the Stickiness of Temporary Sales,” Journal of Monetary Economics 90, 64-83.

Anderson, Eric and Duncan Simester (2003a), "Effects of \$9 Price-Endings on Sales: Evidence from Field Experiments,” Quantitative Marketing and Economics, 1(1), 93110.

Anderson, Eric and Duncan Simester (2003b), “Mind Your Pricing Cues,” Harvard Business Review, 81(9), September, 97-103.

Anderson, Eric and Duncan Simester (2009), "Price Cues and Customer Price Knowledge,” in Vithala R. Rao (Ed.), Handbook of Pricing Research in Marketing (Northampton, MA: Edward Elgar Publishing), pp. 150-166.

Bader, Louis and James D. Weinland (1932), “Do Odd Prices Earn Money?” Journal of Retailing, 8, 102-104.

Barsky, Robert, Mark Bergen, Shantanu Dutta, and Daniel Levy (2003), "What Can the Price Gap between Branded and Private Label Products Tell Us about Markups? In Robert Feenstra and Matthew Shapiro (Eds.), Scanner Data and Price Indexes (Chicago, IL: NBER and the University of Chicago Press), pp. 165-225.

Basu, Kaushik (1997), "Why Are So Many Goods Priced to End in Nine? And Why This Practice Hurts the Producers?” Economics Letters, 54(1), 41-44.

Besley, Timothy, and Harvey Rosen (1999), "Sales Taxes and Prices: An Empirical Analysis,” National Tax Journal, 52, 157-178.

Bhattacharya, Utpal, Craig W. Holden, and Stacey Jacobsen (2012), "Penny Wise, Dollar Foolish: Buy-Sell Imbalances on and Around Round Numbers,” Management Science, 58(2), 413-431.

Blinder, Alan S., Elie R.D. Canetti, David E. Lebow, and Jeremy B. Rudd (1998), Asking about Prices: A New Approach to Understanding Price Stickiness (New York, NY: Russell Sage Foundation).

Carver, James R. and Daniel T. Padgett (2012), “Product Category Pricing and Future Price Attractiveness: 99-Ending Pricing in a Memory-Based Context,” Journal of Retailing, 88(4), 497-511.

Chahrour, Ryan A. (2011), “Sales and Price Spikes in Retail Price Data,” Economics Letters 110, 143-146.

Chakraborty, Ratula, Paul Dobson, Jonathan Seaton, and Michael Waterson (2015), "Pricing in Inflationary Times: the Penny Drops," Journal of Monetary Economics 76, 71-86.

Chen, Haipeng (Allan), Daniel Levy, Sourav Ray, and Mark Bergen (2008), “Asymmetric Price Adjustment in the Small,” Journal of Monetary Economics, 55(4), 728-737.

Chevalier, Judith, Anil Kashyap, and Peter Rossi (2003), "Why Don’t Prices Rise during Periods of Peak Demand? Evidence from Scanner Data,” American Economic Review, 93, 15-37.

Choi, Jungsil, Kiljae Lee, and Yong-Yeon (2012), "What Type of Framing Message Is More Appropriate with Nine-Ending Pricing,” Marketing Letters, 23, 603-614. 
D’Agostino, Ralph B., Albert Belanger, and Ralph B. D’Agostino, Jr. (1990), “A Suggestion for Using Powerful and Informative Tests of Normality,” American Statistician, 44, 316-321.

Dutta, Shantanu, Mark Bergen, and Daniel Levy (2002), "Price Flexibility in Channels of Distribution: Evidence from Scanner Data,” Journal of Economic Dynamics and Control, 26, 1845-1900.

Eichenbaum, Martin, Nir Jaimovich and Sergio Rebelo (2011), "Reference Prices, Costs, and Nominal Rigidities,” American Economic Review 101(1), 234-262.

Freling, Traci, Leslie Vincent, Robert Schindler, David Hardesty, and Jason Rowe (2010), “A Meta-Analytic Review of Just-Below Pricing Effects,” in NA - Advances in Consumer Research, Volume 37, eds. Margaret C. Campbell, Jeff Inman, and Rik Pieters, Duluth, MN: Association for Consumer Research, 618-620.

Gedenk, Karen, and Henrik Sattler (1999), "The Impact of Price Thresholds on Profit Contributions - Should Retailers Set 9-Ending Prices?” Journal of Retailing, 75(1), 33-57.

Gendall, Philip, Michael F. Fox, and Priscilla Wilton (1998), "Estimating the Effect of Odd Pricing,” Journal of Product and Brand Management, 7(5), 421-432.

Ginzberg, Eli (1936), “Customary Prices,” American Economic Review, 26(2), p. 296.

Guimaraes, Bernardo, and Kevin D. Sheedy (2011), "Sales and Monetary Policy” American Economic Review 101(2), 844-876.

Hackl, Franz, Michael E. Kummer, and Rudolf Winter-Ebmer (2014), “99 Cent: Price Points in e-Commerce,” Information Economics and Policy, 26, 12-27.

Holdershaw, Judith, Philip Gendall, and Ron Garland (1997), "The Widespread Use of Odd Pricing in the Retail Sector,” Marketing Bulletin, 8, 53-58.

Jeong, Ji Youn and John L. Crompton (2018), "Do Subjects from High and Low Context Cultures Attribute Different Meanings to Tourism Services with 9-Ending Prices?” Tourism Management, 64, 110-118.

Kalyanam, Kirthi and Thomas S. Shively (1998), "Estimating Irregular Pricing Effects: a Stochastic Spline Regression Approach,” Journal of Marketing Research, 35(1), 1629.

Kashyap, Anil K. (1995), “Sticky Prices: New Evidence from Retail Catalogs,” Quarterly Journal of Economics, 110(1), 245-274.

Klenow, Peter, and Benjamin Malin (2011), “Microeconomic Evidence on Price Setting,” in Friedman, Benjamin and Michael Woodford (Eds.), Handbook of Monetary

Economics, Volume 3A (New York, NY: North Holland), pp. 231-284.

Knotek, Edward, II (2011), “Convenient Prices and Price Rigidity: Cross-Section Evidence,” Review of Economics and Statistics, 93(3), 1076-1086.

Knotek, Edward, II (2019), “The Roles of Price Points and Menu Costs in Price Rigidity” Federal Reserve Bank of Cleveland working paper.

Kreul, Lee M. (1982), "Magic Numbers: Psychological Aspects of Menu Pricing,” Cornell Hotel and Restaurant Administration Quarterly, 22, 70-76.

Lee, Dongwon, Robert J. Kauffman, and Mark E. Bergen (2009), “Image Effects and Rational Inattention in Internet-Based Selling,” International Journal of Electronic Commerce, 13(4), 127-165.

Levy, Daniel, Shantanu Dutta, and Mark Bergen (2002), "Heterogeneity in Price Rigidity: Evidence from Primary Micro-Level Data,” Journal of Money, Credit and Banking, 34, 197-220.

Levy, Daniel, Dongwon Lee, Haipeng (Allan) Chen, Robert Kauffman, and Mark Bergen 
(2011), “Price Points and Price Rigidity,” Review of Economics and Statistics, 93(4), 1417-1431.

Levy, Daniel, Georg Müller, Haipeng (Allan) Chen, Mark Bergen, and Shantanu Dutta (2010), “Holiday Price Rigidity and Cost of Price Adjustment,” Economica, 77, 172198.

Levy, Daniel, Avichai Snir, Alex Gotler, and Haipeng (Allan) Chen (2019), "Not All Price Endings Are Created Equal: Price Points and Asymmetric Price Rigidity,” Journal of Monetary Economics (forthcoming).

Macé, Sandrine (2012), “The Impact and Determinants of Nine-Ending Pricing in Grocery Retailing,” Journal of Retailing, 88(1), 115-130.

Manning, Kenneth C. and David E. Sprott (2009), "Price Endings, Left-Digit Effects, and Choice,” Journal of Consumer Research, 36, 328-355.

Mathä, Thomas Y. (2009), "Regional McParity: Do Common Pricing Points Reduce Deviations from the Law of One Price?” Weltwirtschaftliches Archiv, 145(1), 155166.

Mehrhoff, Jens (2018), “Promoting the Use of a Publically Available Scanner Data set in Price Index Research and for Capacity Building,” Manuscript, European Commission, https://bit.ly/2ZBUbg9.

Meza, Sergio and K. Sudhir (2010), “Do Private Labels Increase Retailer Bargaining Power?” Quantitative Marketing and Economics 8, 333-363.

Midrigan, Virgiliu (2011), "Menu Costs, Multiproduct Firms, and Aggregate Fluctuations,” Econometrica 79(4), 1139-1180.

Nakamura, Emi, and Jón Steinsson (2008), "Five Facts about Prices: a Reevaluation of Menu Cost Models,” Quarterly Journal of Economics, 123(4), 1415-1464.

Ngobo, Paul-Valentin, Patrick Legohérel, Nicolas Guéguen (2010), “A Cross-Category Investigation into the Effects of Nine-Ending Pricing on Brand Choice,” Journal of Retailing and Consumer Services, 17, 374-385.

Peltzman, Sam (2000), “Prices Rise Faster than They Fall,” Journal of Political Economy, 108(3), 466-502.

Quigley Charles J. and Elaine M. Notarantonio (2015), “An Exploratory Investigation of Perceptions of Odd and Even Pricing,” in Crittenden, Victoria L. (Ed.), Proceedings of the 1992 Academy of Marketing Science (AMS) Annual Conference, Developments in Marketing Science: Proceedings of the Academy of Marketing Science (Springer, Cham), pp. 306-309.

Ray, Sourav, Avichai Snir, and Daniel Levy (2019), "Retail Pricing Strategy, Sales, and Price Rigidity,” manuscript in preparation.

Ruffle, Bradley J. and Ze'ev Shtudiner (2006), “99: Are Retailers Best Responding to Rational Consumers? Experimental Evidence,” Managerial and Decision Economics, 27(6), 459-475.

Schindler, Robert M. (1984), “Consumer Recognition of Increases in Odd and Even Prices,” Pp. 459-462 in Advances in Consumer Research, 11. Thomas Kinnear (Ed.), Ann Arbor, MI: Association of Consumer Research.

Schindler, Robert M. (1991), "Symbolic Meanings of a Price Ending,” in Rebecca H. Holman and Michael Solomon (Eds.), Advances in Consumer Research, Vol. 18. Provo, UT: Association for Consumer Research, 794-801.

Schindler, Robert M. (2001), "Relative Price Level of 99-Ending Prices: Image vs Reality,” Marketing Letters, 12(3), 239-247.

Schindler, Robert M. (2006), “The 99 Price-Ending as a Signal of a Low-Price Appeal,” 
Journal of Retailing, 82(1), 71-77.

Schindler, Robert M. and Thomas M. Kibarian (1993), “Testing for Perceptual Underestimation of 9-Ending Prices,” in NA - Advances in Consumer Research, Volume 20, Eds. Leigh McAlister and Michael L. Rothchild, Provo, UT: Association of Consumer Research. Pages: 580-585.

Schindler, Robert M. and Thomas M. Kibarian (1996), "Increased Consumer Sales Response through Use of 99-Ending Prices,” Journal of Retailing, 72, 187-199.

Schindler, Robert M. and Thomas M. Kibarian (2001), "Image Communicated by the Use of 99 Endings in Advertised Prices,” Journal of Advertising, 30(4), 95-99.

Schindler, Robert M. and Patrick N. Kirby (1997), "Patterns of Rightmost Digits Used in Advertised Prices: Implications for Nine-Ending Effects,” Journal of Consumer Research, 24, 192-201.

Schindler, Robert M. and Lori S. Warren (1988), "Effect of Odd Pricing on Choice of Items from a Menu,” Pp. 348-353 in Michael Houston (Ed.), Advances in Consumer Research, 15. Ann Arbor, MI: Association of Consumer Research.

Shlain, Avner S. (2018), "More than a Penny's Worth: Left-Digit Bias and Firm Pricing,” manuscript, University of California, Berkeley.

Snir, Avichai, Daniel Levy, and Haipeng (Allan) Chen (2017), "End of 9-Endings, Price Recall, and Price Perceptions,” Economics Letters, 155, 157-163.

Stiving, Mark (2000), “Price-Endings When Prices Signal Quality,” Management Science, 46(12), 1617-1629.

Stiving, Mark and Russell S. Winer (1997), “An Empirical Analysis of Price Endings Using Scanner Data,” Journal of Consumer Research, 24, 57-67.

Thomas, Manoj and Vicki Morwitz (2005), "Penny Wise and Pound Foolish: the LeftDigit Effect in Price Cognition,” Journal of Consumer Research, 32, 54-64.

Thomas, Manoj and Vicki Morwitz (2009), "Heuristics in Numerical Cognition: Implications for Pricing,” in V. R. Rao (Ed.), Handbook of Pricing Research in Marketing (Northampton, MA: Edward Elgar), pp. 132-149.

Tsiros, Michael, and David M Hardesty (2010), "Ending a Price Promotion: Retracting It in One Step or Phasing It Out Gradually,” Journal of

Marketing 74(1), 49-64.

Twedt, Dik Warren (1965), “Does the '9 Fixation' in Retail Pricing Really Promote Sales?’ Journal of Marketing, 29, 54-55. 
Table 1. Descriptive Statistics of Dominick's Retail Price Data, September 14, 1989-May 8, 1997

\begin{tabular}{|c|c|c|c|c|c|c|c|}
\hline Category & $\begin{array}{c}\text { Number of } \\
\text { Observations }\end{array}$ & $\begin{array}{l}\text { Proportion } \\
\text { of the Total }\end{array}$ & $\begin{array}{l}\text { Number of } \\
\text { Products }\end{array}$ & $\begin{array}{c}\text { Mean } \\
\text { Price (\$) }\end{array}$ & $\begin{array}{l}\text { Std. } \\
\text { Dev. }\end{array}$ & $\begin{array}{c}\text { Min. } \\
\text { Price (\$) }\end{array}$ & $\begin{array}{c}\text { Max. } \\
\text { Price (\$) }\end{array}$ \\
\hline Analgesics & $3,040,172$ & $3.07 \%$ & 638 & 5.18 & 2.36 & 0.02 & 23.69 \\
\hline Bath Soaps & 418,097 & $0.42 \%$ & 579 & 3.16 & 1.60 & 0.01 & 28.00 \\
\hline Beer & $1,966,148$ & $1.99 \%$ & 787 & 5.69 & 2.70 & 0.01 & 29.64 \\
\hline Bottled Juices & $4,325,024$ & $4.37 \%$ & 506 & 2.24 & 0.97 & 0.19 & 9.41 \\
\hline Cereal & $4,707,776$ & $4.76 \%$ & 489 & 3.12 & 0.76 & 0.05 & 26.02 \\
\hline Cheese & $6,752,326$ & $6.83 \%$ & 657 & 2.42 & 1.12 & 0.05 & 84.72 \\
\hline Cigarettes & $1,801,444$ & $1.82 \%$ & 793 & 7.69 & 7.90 & 0.01 & 25.65 \\
\hline Cookies & $7,568,428$ & $7.65 \%$ & 1,124 & 2.10 & 0.63 & 0.02 & 10.99 \\
\hline Crackers & $2,228,269$ & $2.25 \%$ & 330 & 2.01 & 0.57 & 0.01 & 7.29 \\
\hline Canned Soups & $5,504,492$ & $5.56 \%$ & 445 & 1.13 & 0.49 & 0.19 & 8.00 \\
\hline Dish Detergents & $2,164,793$ & $2.19 \%$ & 287 & 2.34 & 0.90 & 0.25 & 15.89 \\
\hline Front-End-Candies & $4,437,054$ & $4.49 \%$ & 503 & 0.61 & 0.24 & 0.01 & 6.99 \\
\hline Frozen Dinners & $1,654,053$ & $1.67 \%$ & 266 & 2.37 & 0.89 & 0.12 & 72.47 \\
\hline Frozen Entrees & $7,172,075$ & $7.25 \%$ & 898 & 2.33 & 1.06 & 0.10 & 15.99 \\
\hline Frozen Juices & $2,368,157$ & $2.39 \%$ & 175 & 1.39 & 0.45 & 0.10 & 6.57 \\
\hline Fabric Softeners & $2,278,995$ & $2.30 \%$ & 318 & 2.82 & 1.45 & 0.01 & 9.99 \\
\hline Grooming products & $4,065,689$ & $4.11 \%$ & 1,380 & 2.94 & 1.37 & 0.01 & 41.70 \\
\hline Laundry Detergents & $3,277,444$ & $3.31 \%$ & 581 & 5.61 & 3.22 & 0.04 & 24.49 \\
\hline Oatmeal & 981,037 & $0.99 \%$ & 96 & 2.65 & 0.66 & 0.25 & 5.00 \\
\hline Paper Towels & 940,757 & $0.95 \%$ & 163 & 1.50 & 1.41 & 0.23 & 13.99 \\
\hline Refrigerated Juices & $2,166,755$ & $2.19 \%$ & 225 & 2.24 & 0.91 & 0.10 & 7.05 \\
\hline Soft Drinks & $10,741,742$ & $10.86 \%$ & 1,608 & 2.34 & 1.89 & 0.01 & 55.55 \\
\hline Shampoos & $4,676,790$ & $4.73 \%$ & 2,930 & 2.95 & 1.86 & 0.02 & 54.99 \\
\hline Snack Crackers & $3,487,564$ & $3.53 \%$ & 420 & 2.18 & 0.57 & 0.02 & 8.00 \\
\hline Soaps & $1,835,196$ & $1.86 \%$ & 334 & 2.51 & 1.48 & 0.01 & 10.99 \\
\hline Toothbrushes & $1,839,536$ & $1.86 \%$ & 491 & 2.18 & 0.85 & 0.20 & 27.52 \\
\hline Tuna & $2,382,983$ & $2.41 \%$ & 278 & 1.80 & 1.07 & 0.11 & 12.89 \\
\hline Toothpastes & $2,981,532$ & $3.01 \%$ & 608 & 2.43 & 0.89 & 0.10 & 19.95 \\
\hline Toilet papers & $1,149,972$ & $1.16 \%$ & 127 & 2.10 & 1.68 & 0.19 & 11.99 \\
\hline Total & $98,914,300$ & $100.00 \%$ & 18,036 & 2.59 & & & \\
\hline
\end{tabular}

Notes

1. The price data are weekly.

2. The figures in the table are based on all price data of Dominick's, in all its 93 stores, for 400 weeks, from September 14, 1989 to May 8, 1997. We exclude 40 observations with prices higher than \$100. 
Table 2. Average 9-Ending and Non 9-Ending Prices, and Percentage Difference between Them, Dominick’s, September 14, 1989-May 8, 1997

\begin{tabular}{|c|c|c|c|}
\hline Category & $\begin{array}{l}\text { (1) } \\
\text { 9-Ending }\end{array}$ & $\begin{array}{c}\text { (2) } \\
\text { Non 9-Ending }\end{array}$ & $\begin{array}{c}(3) \\
\text { \% Difference }\end{array}$ \\
\hline Analgesics & 5.33 & 4.31 & $21.24 \%$ \\
\hline Bath Soaps & 3.15 & 3.24 & $-2.82 \%$ \\
\hline Beer & 5.68 & 5.83 & $-2.61 \%$ \\
\hline Bottled Juices & 2.27 & 2.22 & $2.23 \%$ \\
\hline Cereal & 3.08 & 3.14 & $-1.93 \%$ \\
\hline Cheese & 2.53 & 2.42 & $4.45 \%$ \\
\hline Cigarettes & 11.93 & 6.85 & $55.48 \%$ \\
\hline Cookies & 2.06 & 2.21 & $-7.03 \%$ \\
\hline Crackers & 2.08 & 1.90 & $9.05 \%$ \\
\hline Canned Soups & 1.21 & 1.09 & $10.44 \%$ \\
\hline Dish Detergents & 2.36 & 2.30 & $2.58 \%$ \\
\hline Front-End-Candies & 0.74 & 0.53 & $33.38 \%$ \\
\hline Frozen Dinners & 2.33 & 2.42 & $-3.79 \%$ \\
\hline Frozen Entrees & 2.34 & 2.32 & $0.86 \%$ \\
\hline Frozen Juices & 1.32 & 1.44 & $-8.70 \%$ \\
\hline Fabric Softeners & 2.88 & 2.74 & $4.98 \%$ \\
\hline Grooming products & 3.02 & 2.42 & $22.15 \%$ \\
\hline Laundry Detergents & 5.76 & 5.11 & $11.97 \%$ \\
\hline Oatmeal & 2.65 & 2.66 & $-0.38 \%$ \\
\hline Paper Towels & 1.69 & 1.30 & $26.24 \%$ \\
\hline Refrigerated Juices & 2.28 & 2.19 & $5.51 \%$ \\
\hline Soft Drinks & 2.53 & 1.44 & $56.36 \%$ \\
\hline Shampoos & 3.00 & 2.44 & $20.66 \%$ \\
\hline Snack Crackers & 2.20 & 2.12 & $3.25 \%$ \\
\hline Soaps & 2.74 & 2.12 & $25.65 \%$ \\
\hline Toothbrushes & 2.21 & 2.09 & $5.58 \%$ \\
\hline Tuna & 1.99 & 1.63 & $19.96 \%$ \\
\hline Toothpastes & 2.53 & 2.26 & $11.29 \%$ \\
\hline Toilet papers & 2.51 & 1.64 & $42.56 \%$ \\
\hline $\begin{array}{l}\text { Average of the Positive \% } \\
\text { Differences }\end{array}$ & & & $17.99 \%$ \\
\hline
\end{tabular}

Notes

In columns (1) and (2), we report the average 9-ending and non 9-ending prices, respectively, in each one of Dominick's 29 product categories, calculated over all stores and weeks. In column (3), we report the percentage difference between the average 9-ending and non 9-ending prices computed as a log-difference. The 22 categories with positive values in column (3) are indicated in italic boldface. All the differences are statistically significant based on the Mann-Whitney test with $p<0.01$. 
Table 3. Moments of the Distribution of the Percentage Differences between the Average 9Ending and the Average Non 9-Ending Prices, Dominick’s, September 14, 1989-May 8, 1997

\begin{tabular}{|c|c|c|c|c|c|c|}
\hline Category & Median & Average & Std. Dev. & Skewness & Kurtosis & $N$ \\
\hline Analgesics & $7.3 \%$ & $8.8 \%$ & $15.1 \%$ & $5.85^{* * *}$ & $175.71^{* * *}$ & 21,360 \\
\hline Bath Soaps & $17.9 \%$ & $20.7 \%$ & $20.5 \%$ & $1.93 * * *$ & $25.78 * * *$ & 5,125 \\
\hline Beer & $0.1 \%$ & $1.8 \%$ & $10.9 \%$ & $13.87 * * *$ & $671.37 * * *$ & 12,224 \\
\hline Bottled Juices & $-0.0 \%$ & $0.4 \%$ & $13.5 \%$ & $0.44^{* * *}$ & $17.28 * * *$ & 30,962 \\
\hline Cereal & $0.5 \%$ & $-0.1 \%$ & $115.5 \%$ & $-0.19 * * *$ & $15.38 * * *$ & 28,530 \\
\hline Cheese & $3.6 \%$ & $4.0 \%$ & $12.2 \%$ & $-0.28 * * *$ & $20.26 * * *$ & 41,122 \\
\hline Cigarettes & $3.8 \%$ & $3.3 \%$ & $8.2 \%$ & $0.95^{* * *}$ & $43.75^{* * *}$ & 15,385 \\
\hline Cookies & $4.9 \%$ & $4.8 \%$ & $14.5 \%$ & $-0.35^{* * *}$ & $22.32 * * *$ & 57,404 \\
\hline Crackers & $6.7 \%$ & $6.2 \%$ & $12.5 \%$ & $-1.38 * * *$ & $23.37 * * *$ & 17,608 \\
\hline Canned Soups & $1.3 \%$ & $0.1 \%$ & $12.4 \%$ & $-0.67 * * *$ & $6.00 * * *$ & 29,272 \\
\hline Dish Detergents & $1.0 \%$ & $-0.5 \%$ & $11.9 \%$ & $-0.06 * * *$ & $6.89 * * *$ & 16,191 \\
\hline Front-End-Candies & $6.0 \%$ & $10.2 \%$ & $23.7 \%$ & $0.86^{* * *}$ & $6.89 * * *$ & 20,819 \\
\hline Frozen Dinners & $7.0 \%$ & $5.0 \%$ & $21.5 \%$ & $-1.03 * * *$ & $7.95^{* * *}$ & 17,534 \\
\hline Frozen Entrees & $4.4 \%$ & $0.3 \%$ & $30.0 \%$ & $-1.03 * * *$ & $5.47 * * *$ & 55,140 \\
\hline Frozen Juices & $-5.4 \%$ & $-5.8 \%$ & $12.4 \%$ & $0.86^{* * *}$ & $18.43^{* * *}$ & 12,269 \\
\hline Fabric Softeners & $2.0 \%$ & $1.7 \%$ & $12.6 \%$ & $1.78^{* * *}$ & $15.34 * * *$ & 19,172 \\
\hline Grooming products & $15.1 \%$ & $15.7 \%$ & $19.2 \%$ & 0.01 & $9.78 * * *$ & 54,048 \\
\hline Laundry Detergents & $1.8 \%$ & $3.0 \%$ & $12.1 \%$ & $1.30 * * *$ & $10.81 * * *$ & 33,057 \\
\hline Oatmeal & $3.5 \%$ & $3.0 \%$ & $17.6 \%$ & $-0.33 * * *$ & $7.39 * * *$ & 5,844 \\
\hline Paper Towels & $-1.3 \%$ & $-2.1 \%$ & $15.8 \%$ & $-1.48 * * *$ & $21.17 * * *$ & 7,245 \\
\hline Refrigerated Juices & $0.5 \%$ & $0.6 \%$ & $11.8 \%$ & $1.34 * * *$ & $17.75^{* * *}$ & 14,867 \\
\hline Soft Drinks & $10.9 \%$ & $12.2 \%$ & $22.8 \%$ & $1.86^{* * *}$ & $45.34 * * *$ & 74,387 \\
\hline Shampoos & $17.1 \%$ & $17.8 \%$ & $18.0 \%$ & $0.67 * * *$ & $7.16^{* * *}$ & 63,011 \\
\hline Snack Crackers & $5.4 \%$ & $5.5 \%$ & $12.0 \%$ & $2.02 * * *$ & $250.37 * * *$ & 25,042 \\
\hline Soaps & $2.7 \%$ & $4.1 \%$ & $15.0 \%$ & $2.20 * * *$ & $18.98 * * *$ & 17,442 \\
\hline Toothbrushes & $5.3 \%$ & $5.0 \%$ & $17.6 \%$ & $0.18^{* * *}$ & $6.02 * * *$ & 18,940 \\
\hline Tuna & $1.3 \%$ & $0.4 \%$ & $11.0 \%$ & $-1.44 * * *$ & $16.12^{* * *}$ & 16,324 \\
\hline Toothpastes & $2.2 \%$ & $2.7 \%$ & $15.8 \%$ & $1.05^{* * *}$ & $10.09 * * *$ & 27,731 \\
\hline Toilet papers & $0.7 \%$ & $0.4 \%$ & $10.5 \%$ & $0.50 * * *$ & $8.29 * * *$ & 8,252 \\
\hline
\end{tabular}

Notes

In the table, we report the descriptive statistics of the distribution of the percentage difference between the average 9-ending and the average non 9-ending prices, at the product-store level, by product category. Skewness statistic is estimated using Fischer's Skewness Measure. Its statistical significance is based on the test of D'Agostino, et al (1990), which compares the skewness in a given sample to the skewness of the normal distribution, where the latter equals 0 . Kurtosis statistic is estimated using the Moment Coefficient of Kurtosis. Its statistical significance test compares it, in a given sample, to the kurtosis of the normal distribution, which equals $3 . * * *$ indicates statistical significance at the $p<0.01$ level. 
Table 4. The Share of 9-Ending Prices, Dominick’s, 1989-1997

\begin{tabular}{|ll|}
\hline \hline Year & Share \\
\hline \hline 1989 & $51.9 \%$ \\
1990 & $54.7 \%$ \\
1991 & $55.8 \%$ \\
1992 & $63.9 \%$ \\
1993 & $63.8 \%$ \\
1994 & $67.2 \%$ \\
1995 & $66.7 \%$ \\
1996 & $68.9 \%$ \\
\hline 1997 & $73.0 \%$ \\
\hline
\end{tabular}

$\underline{\text { Notes }}$

In the table, we present the share of 9-ending prices across all Dominick's stores, for each year from 1989 to 1997. 
Table 5. Regression Analyses of the Percentage Difference between 9-Ending and Non 9Ending Prices, Dominick’s, September 14, 1989-May 8, 1997

\begin{tabular}{|c|c|c|c|c|}
\hline & (1) & (2) & (3) & $N$ \\
\hline Analgesics & $0.13(0.005)^{* * *}$ & $0.13(0.005)^{* * *}$ & $0.15(0.0007)^{* * *}$ & $3,3,040,172$ \\
\hline Bath Soaps & $0.02(0.010)^{* *}$ & $0.03(0.010)^{* * *}$ & $0.12(0.001)^{* * *}$ & 418,097 \\
\hline Beer & $0.03(0.009)^{* * *}$ & $0.03(0.009)^{* * *}$ & $-0.02(0.001)^{* * *}$ & $1,966,148$ \\
\hline Bottled Juices & $0.03(0.003)^{* * *}$ & $0.03(0.003)^{* * *}$ & $0.02(0.000)^{* * *}$ & $4,325,024$ \\
\hline Cereal & $-0.02(0.001)^{* * *}$ & $-0.02(0.001)^{* * *}$ & $0.01(0.000)^{* * *}$ & $4,707,776$ \\
\hline Cheese & $0.11(0.002)^{* * *}$ & $0.08(0.001)^{* * *}$ & $0.15(0.000)^{* * *}$ & $6,752,326$ \\
\hline Cigarettes & $0.59(0.059)^{* * *}$ & $0.02(0.005)^{* * *}$ & $0.27(0.001)^{* * *}$ & $1,801,444$ \\
\hline Cookies & $-0.09(0.003)^{* * *}$ & $0.00(0.002)$ & $-0.003(0.000)^{* * *}$ & $7,568,352$ \\
\hline Crackers & $0.06(0.001)^{* * *}$ & $0.07(0.001)^{* * *}$ & $0.03(0.000)^{* * *}$ & $2,228,268$ \\
\hline Canned Soups & $0.09(0.005)^{* * *}$ & $0.09(0.005)^{* * *}$ & $0.06(0.000)^{* * *}$ & $5,504,492$ \\
\hline Dish Detergents & $0.03(0.006)^{* * *}$ & $0.03(0.004)^{* * *}$ & $0.02(0.000)^{* * *}$ & $2,164,793$ \\
\hline Front-End-Candies & $0.39(0.002)^{* * *}$ & $0.38(0.002)^{* * *}$ & $0.24(0.003)^{* * *}$ & $4,437,054$ \\
\hline Frozen Dinners & $-0.01(0.007)^{*}$ & $-0.01(0.007)$ & $0.04(0.000)^{* * *}$ & $1,654,053$ \\
\hline Frozen Entrees & $0.06(0.005)^{* * *}$ & $0.05(0.005)^{* * *}$ & $0.009(0.000)^{* * *}$ & $7,172,075$ \\
\hline Frozen Juices & $-0.07(0.003)^{* * *}$ & $-0.08(0.003)^{* * *}$ & $-0.06(0.000)^{* * *}$ & $2,368,157$ \\
\hline Fabric Softeners & $-0.03(0.003)^{* * *}$ & $-0.03(0.003)^{* * *}$ & $0.02(0.001)^{* * *}$ & $2,278,995$ \\
\hline Grooming products & $0.21(0.002)^{* * *}$ & $0.16(0.002)^{* * *}$ & $0.17(0.000)^{* * *}$ & $4,065,689$ \\
\hline Laundry Detergents & $0.10(0.003)^{* * *}$ & $0.13(0.002)^{* * *}$ & $0.12(0.001)^{* * *}$ & $3,277,444$ \\
\hline Oatmeal & $-0.02(0.006)^{* * *}$ & $-0.01(0.006)^{*}$ & $0.01(0.004)^{* * *}$ & 981,037 \\
\hline Paper Towels & $0.14(0.010)^{* * *}$ & $0.14(0.010)^{* * *}$ & $0.05(0.001)^{* * *}$ & 940,757 \\
\hline Refrigerated Juices & $0.06(0.004)^{* * *}$ & $0.06(0.004)^{* * *}$ & $0.06(0.001)^{* * *}$ & $2,166,755$ \\
\hline Soft Drinks & $0.69(0.010)^{* * *}$ & $0.30(0.005)^{* * *}$ & $0.30(0.000)^{* * *}$ & $10,741,742$ \\
\hline Shampoos & $0.16(0.012)^{* * *}$ & $0.12(0.009)^{* * *}$ & $0.12(0.000)^{* * *}$ & $4,666,565$ \\
\hline Snack Crackers & $0.03(0.004)^{* * *}$ & $0.03(0.004)^{* * *}$ & $0.05(0.000)^{* * *}$ & $3,487,564$ \\
\hline Soaps & $0.15(0.003)^{* * *}$ & $0.15(0.003)^{* * *}$ & $0.11(0.006)^{* * *}$ & $1,835,196$ \\
\hline Toothbrushes & $-0.03(0.005)^{* * *}$ & $-0.01(0.005)^{* * *}$ & $0.02(0.000)^{* * *}$ & $1,772,158$ \\
\hline Tuna & $0.19(0.003)^{* * *}$ & $0.19(0.003)^{* * *}$ & $0.10(0.001)^{* * *}$ & $2,382,983$ \\
\hline Toothpastes & $0.01(0.004)$ & $0.01(0.004)^{* * *}$ & $-0.01(0.003)^{* * *}$ & $2,981,532$ \\
\hline Toilet papers & $0.41(0.007)^{* * *}$ & $0.41(0.007)^{* * *}$ & $0.11(0.001)^{* * *}$ & $1,149,972$ \\
\hline Dummies for weeks & $\sqrt{ }$ & & $\sqrt{ }$ & \\
\hline $\begin{array}{l}\text { Dummies for product- } \\
\text { store }\end{array}$ & & & $\sqrt{ }$ & \\
\hline $\begin{array}{l}\text { Dummies for sub- } \\
\text { categories-store }\end{array}$ & $\sqrt{ }$ & & & \\
\hline $\begin{array}{l}\text { Dummies for sub- } \\
\text { categories-store-weeks }\end{array}$ & & $\sqrt{ }$ & & \\
\hline
\end{tabular}

$\underline{\text { Notes }}$

In the table, we report the coefficient estimates of a 9-ending dummy in OLS regressions with fixed effects, where the dependent variable is the log of the prices. The 9-ending dummy equals 1 if the price ends with 9 , and 0 if the price ends with any other digit. In column (1), the regression includes controls for weeks and for subcategoriesstore. In column (2), the regression includes controls for subcategories-stores-weeks. In column (3), the regression includes dummies for weeks and for product-store. In parentheses, we report robust standard errors, clustered at the store level. $* p<10 \%, * * p<5 \%, * * * p<1 \%$. 
Table 6. The Share of 9-Ending Prices by Product Categories, Using Dominick’s Sale Dummy, September 14, 1989-May 8, 1997

\begin{tabular}{|c|c|c|c|}
\hline Category & $\begin{array}{c}\text { (1) } \\
\text { Sale Prices }\end{array}$ & $\begin{array}{c}\text { (2) } \\
\text { Regular Prices }\end{array}$ & $\begin{array}{c}\text { (3) } \\
\text { Difference }\end{array}$ \\
\hline Analgesics & $69.2 \%$ & $87.6 \%$ & $-18.4 \%$ \\
\hline Bath Soaps & $61.8 \%$ & $91.6 \%$ & $-29.8 \%$ \\
\hline Beer & $95.6 \%$ & $95.8 \%$ & $-0.2 \%$ \\
\hline Bottled Juices & $42.3 \%$ & $52.7 \%$ & $-10.4 \%$ \\
\hline Cereal & $41.1 \%$ & $39.6 \%$ & $1.6 \%$ \\
\hline Cheese & $46.5 \%$ & $64.6 \%$ & $-18.1 \%$ \\
\hline Cigarettes & $100.0 \%$ & $16.5 \%$ & $83.6 \%$ \\
\hline Cookies & $45.2 \%$ & $79.8 \%$ & $-34.6 \%$ \\
\hline Crackers & $35.5 \%$ & $72.3 \%$ & $-36.8 \%$ \\
\hline Canned Soups & $26.3 \%$ & $31.7 \%$ & $-5.4 \%$ \\
\hline Dish Detergents & $57.7 \%$ & $68.8 \%$ & $-11.1 \%$ \\
\hline Front-End-Candies & $21.8 \%$ & $40.7 \%$ & $-18.9 \%$ \\
\hline Frozen Dinners & $28.9 \%$ & $65.7 \%$ & $-6.8 \%$ \\
\hline Frozen Entrees & $25.6 \%$ & $67.8 \%$ & $-42.2 \%$ \\
\hline Frozen Juices & $48.8 \%$ & $45.8 \%$ & $3.0 \%$ \\
\hline Fabric Softeners & $54.4 \%$ & $60.3 \%$ & $-5.9 \%$ \\
\hline Grooming products & $60.0 \%$ & $92.2 \%$ & $-32.2 \%$ \\
\hline Laundry Detergents & $64.2 \%$ & $78.6 \%$ & $-14.4 \%$ \\
\hline Oatmeal & $37.1 \%$ & $53.9 \%$ & $-16.8 \%$ \\
\hline Paper Towels & $45.0 \%$ & $51.4 \%$ & $-6.4 \%$ \\
\hline Refrigerated Juices & $55.9 \%$ & $57.1 \%$ & $-1.2 \%$ \\
\hline Soft Drinks & $69.3 \%$ & $88.6 \%$ & $-19.3 \%$ \\
\hline Shampoos & $79.3 \%$ & $94.2 \%$ & $-14.9 \%$ \\
\hline Snack Crackers & $43.1 \%$ & $81.3 \%$ & $-38.2 \%$ \\
\hline Soaps & $44.2 \%$ & $66.2 \%$ & $-22.0 \%$ \\
\hline Toothbrushes & $70.0 \%$ & $79.2 \%$ & $-9.2 \%$ \\
\hline Tuna & $33.7 \%$ & $52.4 \%$ & $-18.7 \%$ \\
\hline Toothpastes & $65.4 \%$ & $63.5 \%$ & $1.9 \%$ \\
\hline Toilet papers & $52.0 \%$ & $53.7 \%$ & $-1.7 \%$ \\
\hline $\begin{array}{l}\text { Average of the Negative } \\
\text { Differences }\end{array}$ & & & $-18.5 \%$ \\
\hline
\end{tabular}

Notes

We use Dominick's sale dummy indicator to identify sale prices. In column (1), we report the percentage of 9-ending prices among sale prices. In column (2), we report the percentage of 9-ending prices among regular prices. In column (3), we report the difference between the percentage of 9-ending prices among sale prices and among regular prices. All differences are statistically significant with $p<0.01$, based on the $z$-scores proportions test. 
Table 7. Regression Analysis of the Percentage Difference between 9-Ending and Non 9-Ending Prices, Regular Prices vs Sale Prices, Using Dominick’s Sale Dummy, September 14, 1989-May 8, 1997

\begin{tabular}{|c|c|c|c|c|c|c|c|c|}
\hline & \multicolumn{4}{|c|}{ Regular Prices } & \multicolumn{4}{|c|}{ Sale Prices } \\
\hline & (1) & $\overline{~(2) ~}$ & (3) & $N$ & (4) & (5) & $\overline{(16)}$ & $N$ \\
\hline Analgesics & $\begin{array}{c}0.14^{* * *} \\
(0.005)\end{array}$ & $\begin{array}{c}0.14^{* * *} \\
(0.006)\end{array}$ & $\begin{array}{c}0.16^{* * * *} \\
(0.001)\end{array}$ & $2,782,538$ & $\begin{array}{c}-0.01^{* * *} \\
(0.002)\end{array}$ & $\begin{array}{l}-0.00 \\
(0.002)\end{array}$ & $\begin{array}{l}-0.00^{* *} \\
(0.002)\end{array}$ & 257,634 \\
\hline Bath Soaps & $\begin{array}{c}-0.09 * * * \\
(0.015)\end{array}$ & $\begin{array}{c}-0.09 * * * \\
(0.014)\end{array}$ & $\begin{array}{c}0.06 * * * \\
(0.001)\end{array}$ & 372,448 & $\begin{array}{c}0.07 * * * \\
(0.009)\end{array}$ & $\begin{array}{c}0.06 * * * \\
(0.007)\end{array}$ & $\begin{array}{c}0.00 \\
(0.002)\end{array}$ & 45,649 \\
\hline Beer & $\begin{array}{c}-0.13^{* * *} \\
(0.006)\end{array}$ & $\begin{array}{c}-0.11^{* * *} \\
(0.006)\end{array}$ & $\begin{array}{c}-0.008 * * * \\
(0.001)\end{array}$ & $1,421,725$ & $\begin{array}{c}0.36 * * * \\
(0.017)\end{array}$ & $\begin{array}{c}0.34^{* * *} \\
(0.017)\end{array}$ & $\begin{array}{c}0.13^{* * *} \\
(0.002)\end{array}$ & 544,423 \\
\hline Bottled Juices & $\begin{array}{c}0.04^{* * *} \\
(0.003)\end{array}$ & $\begin{array}{c}0.03 * * * \\
(0.003)\end{array}$ & $\begin{array}{c}0.03 * * * \\
(0.00)\end{array}$ & $3,482,485$ & $\begin{array}{c}-0.02 * * * \\
(0.002)\end{array}$ & $\begin{array}{c}-0.03 * * * \\
(0.003)\end{array}$ & $\begin{array}{c}-0.03^{* * *} \\
(0.001)\end{array}$ & 842,539 \\
\hline Cereal & $\begin{array}{c}-0.02 * * * \\
(0.001)\end{array}$ & $\begin{array}{c}-0.02^{* * *} \\
(0.001)\end{array}$ & $\begin{array}{l}0.01 * * * \\
(0.000)\end{array}$ & $4,365,153$ & $\begin{array}{c}0.02 * * * \\
(0.002)\end{array}$ & $\begin{array}{c}0.00 \\
(0.002)\end{array}$ & $\begin{array}{c}-0.02^{* * *} \\
(0.001)\end{array}$ & 342,623 \\
\hline Cheese & $\begin{array}{c}0.12^{* * *} \\
(0.003)\end{array}$ & $\begin{array}{c}0.09 * * * \\
(0.002)\end{array}$ & $\begin{array}{c}0.18^{* * *} \\
(0.000)\end{array}$ & $5,559,438$ & $\begin{array}{c}-0.02^{* * *} \\
(0.002)\end{array}$ & $\begin{array}{l}-0.00 \\
(0.002)\end{array}$ & $\begin{array}{c}-0.00^{* * *} \\
(0.001)\end{array}$ & 1,192,888 \\
\hline Cigarettes & $\begin{array}{c}0.59 * * * \\
(0.058)\end{array}$ & $\begin{array}{c}0.02^{* * *} \\
(0.005)\end{array}$ & $\begin{array}{c}0.27^{* * *} \\
(0.01)\end{array}$ & $1,801,423$ & NA & NA & NA & 21 \\
\hline Cookies & $\begin{array}{c}-0.14 * * * \\
(0.003)\end{array}$ & $\begin{array}{c}-0.03 * * * \\
(0.006)\end{array}$ & $\begin{array}{c}-0.04 * * * \\
(0.000)\end{array}$ & $6,289,751$ & $\begin{array}{c}-0.09^{* * *} \\
(0.003)\end{array}$ & $\begin{array}{c}-0.06^{* * *} \\
(0.002)\end{array}$ & $\begin{array}{c}-0.07^{* * *} \\
(0.000)\end{array}$ & 1,278,677 \\
\hline Crackers & $\begin{array}{c}0.08 * * * \\
(0.001)\end{array}$ & $\begin{array}{c}0.09 * * * \\
(0.001)\end{array}$ & $\begin{array}{c}0.02 * * * \\
(0.000)\end{array}$ & $1,726,858$ & $\begin{array}{c}-0.06 * * * \\
(0.002)\end{array}$ & $\begin{array}{c}-0.07 * * * \\
(0.001)\end{array}$ & $\begin{array}{c}-0.05^{* * *} \\
(0.001)\end{array}$ & 501,410 \\
\hline Canned Soups & $\begin{array}{c}0.10^{* * * *} \\
(0.006)\end{array}$ & $\begin{array}{c}0.09 * * * \\
(0.006)\end{array}$ & $\begin{array}{c}0.07 * * * \\
(0.000)\end{array}$ & $4,806,570$ & $\begin{array}{c}0.03^{* * *} \\
(0.003)\end{array}$ & $\begin{array}{c}0.05 * * * \\
(0.003)\end{array}$ & $\begin{array}{c}-0.01^{* * *} \\
(0.000)\end{array}$ & 697,922 \\
\hline Dish Detergents & $\begin{array}{c}0.04 * * * \\
(0.008)\end{array}$ & $\begin{array}{c}0.05^{* * * *} \\
(0.004)\end{array}$ & $\begin{array}{c}0.03 * * * \\
(0.000)\end{array}$ & $1,871,492$ & $\begin{array}{c}-0.07 * * * \\
(0.002)\end{array}$ & $\begin{array}{c}-0.07 * * * \\
(0.002)\end{array}$ & $\begin{array}{c}-0.06^{* * * *} \\
(0.001)\end{array}$ & 293,301 \\
\hline $\begin{array}{l}\text { Front-End- } \\
\text { Candies }\end{array}$ & $\begin{array}{c}0.40 * * * \\
(0.002)\end{array}$ & $\begin{array}{c}0.39 * * * \\
(0.003)\end{array}$ & $\begin{array}{c}0.24^{* * *} \\
(0.000)\end{array}$ & $4,025,320$ & $\begin{array}{c}0.07 * * * \\
(0.004)\end{array}$ & $\begin{array}{c}0.04 * * * \\
(0.004)\end{array}$ & $\begin{array}{c}-0.01 \\
(0.002)\end{array}$ & 411,734 \\
\hline Frozen Dinners & $\begin{array}{c}-0.07 * * * \\
(0.007)\end{array}$ & $\begin{array}{c}-0.07 * * * \\
(0.007)\end{array}$ & $\begin{array}{c}0.01 * * * \\
(0.003)\end{array}$ & $1,254,403$ & $\begin{array}{c}-0.01 \\
(0.009)\end{array}$ & $\begin{array}{c}-0.03^{* * *} \\
(0.009)\end{array}$ & $\begin{array}{c}-0.07 * * * \\
(0.001)\end{array}$ & 399,650 \\
\hline Frozen Entrees & $\begin{array}{c}0.09 * * * \\
(0.003)\end{array}$ & $\begin{array}{c}0.08 * * * \\
(0.002)\end{array}$ & $\begin{array}{c}0.02 * * * \\
(0.000)\end{array}$ & $5,830,824$ & $\begin{array}{c}-0.19 * * * \\
(0.006)\end{array}$ & $\begin{array}{c}-0.23 * * * \\
(0.007)\end{array}$ & $\begin{array}{c}-0.20 * * * \\
(0.001)\end{array}$ & $1,341,251$ \\
\hline Frozen Juices & $\begin{array}{c}-0.05^{* * *} \\
(0.002)\end{array}$ & $\begin{array}{c}-0.06 * * * \\
(0.003)\end{array}$ & $\begin{array}{c}-0.04 * * * \\
(0.000)\end{array}$ & $1,915,472$ & $\begin{array}{c}-0.19 * * * \\
(0.006)\end{array}$ & $\begin{array}{c}-0.19 * * * \\
(0.007)\end{array}$ & $\begin{array}{c}-0.12^{* * *} \\
(0.001)\end{array}$ & 452,685 \\
\hline Fabric Softeners & $\begin{array}{c}-0.05^{* * *} \\
(0.003)\end{array}$ & $\begin{array}{c}-0.06 * * * \\
(0.003)\end{array}$ & $\begin{array}{c}0.01 * * * \\
(0.001)\end{array}$ & $1,947,002$ & $\begin{array}{c}0.10^{* * *} \\
(0.004)\end{array}$ & $\begin{array}{c}0.13^{* * *} \\
(0.002)\end{array}$ & $\begin{array}{l}0.00^{* *} \\
(0.001)\end{array}$ & 331,993 \\
\hline $\begin{array}{l}\text { Grooming } \\
\text { products }\end{array}$ & $\begin{array}{c}0.07 * * * \\
(0.003)\end{array}$ & $\begin{array}{c}0.04 * * * \\
(0.004)\end{array}$ & $\begin{array}{c}0.08 * * * \\
(0.001)\end{array}$ & $3,379,005$ & $\begin{array}{l}0.21 * * * \\
(0.003)\end{array}$ & $\begin{array}{l}0.12^{* * *} \\
(0.002)\end{array}$ & $\begin{array}{l}0.11^{* * *} \\
(0.001)\end{array}$ & 686,684 \\
\hline $\begin{array}{l}\text { Laundry } \\
\text { Detergents }\end{array}$ & $\begin{array}{c}0.07 * * * \\
(0.003)\end{array}$ & $\begin{array}{c}0.11 * * * \\
(0.003)\end{array}$ & $\begin{array}{c}0.12 * * * \\
(0.001)\end{array}$ & 2,783,222 & $\begin{array}{c}0.20 * * * \\
(0.003)\end{array}$ & $\begin{array}{c}0.19 * * * \\
(0.003)\end{array}$ & $\begin{array}{c}0.07 * * * \\
(0.001)\end{array}$ & 494,222 \\
\hline Oatmeal & $\begin{array}{c}-0.03^{* * *} \\
(0.005)\end{array}$ & $\begin{array}{c}-0.03^{* * *} \\
(0.006)\end{array}$ & $\begin{array}{c}0.00 * * * \\
(0.000)\end{array}$ & 884,061 & $\begin{array}{c}-0.03 * * * \\
(0.004)\end{array}$ & $\begin{array}{c}0.01 \\
(0.004)\end{array}$ & $\begin{array}{c}-0.03^{* * *} \\
(0.001)\end{array}$ & 96,976 \\
\hline Paper Towels & $\begin{array}{c}0.15^{* * *} \\
(0.011)\end{array}$ & $\begin{array}{c}0.15^{* * *} \\
(0.011)\end{array}$ & $\begin{array}{c}0.06^{* * * *} \\
(0.001)\end{array}$ & 740,148 & $\begin{array}{c}0.05^{* * *} \\
(0.006)\end{array}$ & $\begin{array}{c}0.04^{* * *} \\
(0.006)\end{array}$ & $\begin{array}{c}0.02 * * * \\
(0.002)\end{array}$ & 200,609 \\
\hline $\begin{array}{l}\text { Refrigerated } \\
\text { Juices }\end{array}$ & $\begin{array}{c}0.09 * * * \\
(0.005)\end{array}$ & $\begin{array}{c}0.09 * * * \\
(0.005)\end{array}$ & $\begin{array}{c}0.08^{* * *} \\
(0.001)\end{array}$ & $1,649,385$ & $\begin{array}{c}-0.01^{* * *} \\
(0.002)\end{array}$ & $\begin{array}{c}-0.02^{* * *} \\
(0.002)\end{array}$ & $\begin{array}{c}-0.00 * * \\
(0.000)\end{array}$ & 517,370 \\
\hline Soft Drinks & $\begin{array}{c}0.84^{* * * *} \\
(0.011)\end{array}$ & $\begin{array}{c}0.43 * * * \\
(0.005)\end{array}$ & $\begin{array}{c}0.42 * * * \\
(0.001)\end{array}$ & $7,458,955$ & $\begin{array}{c}0.60 * * * \\
(0.009)\end{array}$ & $\begin{array}{c}0.11^{* * *} \\
(0.004)\end{array}$ & $\begin{array}{c}0.13^{* * *} \\
(0.001)\end{array}$ & $3,282,787$ \\
\hline Shampoos & $\begin{array}{c}0.13^{* * *} \\
(0.017)\end{array}$ & $\begin{array}{c}0.09 * * * \\
(0.013)\end{array}$ & $\begin{array}{c}0.05^{* * *} \\
(0.000)\end{array}$ & $3,817,736$ & $\begin{array}{c}-0.03 * * * \\
(0.004)\end{array}$ & $\begin{array}{c}-0.05^{* * *} \\
(0.003)\end{array}$ & $\begin{array}{c}0.02^{* * *} \\
(0.001)\end{array}$ & 848,829 \\
\hline Snack Crackers & $\begin{array}{c}0.01 \\
(0.007)\end{array}$ & $\begin{array}{c}0.01 \\
(0.006)\end{array}$ & $\begin{array}{c}0.04^{* * *} \\
(0.000)\end{array}$ & 2,704,331 & $\begin{array}{c}-0.04 * * * \\
(0.003)\end{array}$ & $\begin{array}{c}-0.04^{* * *} \\
(0.003)\end{array}$ & $\begin{array}{c}-0.06 * * * \\
(0.000)\end{array}$ & 783,233 \\
\hline Soaps & $\begin{array}{c}0.16^{* * * *} \\
(0.005)\end{array}$ & $\begin{array}{c}0.15^{* * *} \\
(0.004)\end{array}$ & $\begin{array}{c}0.12 * * * \\
(0.001)\end{array}$ & $1,544,719$ & $\begin{array}{c}0.11^{* * *} \\
(0.002)\end{array}$ & $\begin{array}{c}0.12 * * * \\
(0.002)\end{array}$ & $\begin{array}{c}0.03^{* * *} \\
(0.001)\end{array}$ & 290477 \\
\hline
\end{tabular}




\begin{tabular}{|c|c|c|c|c|c|c|c|c|}
\hline Toothbrushes & $\begin{array}{c}-0.05^{* * * *} \\
(0.005)\end{array}$ & $\begin{array}{c}-0.03 * * * \\
(0.005)\end{array}$ & $\begin{array}{c}0.00 \\
(0.001)\end{array}$ & $1,472,393$ & $\begin{array}{c}-0.03 \\
(0.004)\end{array}$ & $\begin{array}{c}-0.02 \\
(0.003)\end{array}$ & $\begin{array}{c}-0.04 * * * \\
(0.001)\end{array}$ & 299765 \\
\hline Tuna & $\begin{array}{c}0.21 * * * \\
(0.003)\end{array}$ & $\begin{array}{l}0.22 * * * \\
(0.003)\end{array}$ & $\begin{array}{c}0.11 * * * \\
(0.001)\end{array}$ & $1,950,555$ & $\begin{array}{c}-0.01^{* * *} \\
(0.004)\end{array}$ & $\begin{array}{c}-0.01 \\
(0.004)\end{array}$ & $\begin{array}{c}-0.01 * * * \\
(0.002)\end{array}$ & 432,428 \\
\hline Toothpastes & $\begin{array}{l}-0.01 * \\
(0.005)\end{array}$ & $\begin{array}{c}-0.00 \\
(0.004)\end{array}$ & $\begin{array}{c}-0.02^{* * *} \\
(0.000)\end{array}$ & $2,534,793$ & $\begin{array}{c}0.02 * * * \\
(0.002)\end{array}$ & $\begin{array}{c}0.04 * * * \\
(0.002)\end{array}$ & $\begin{array}{c}-0.02 * * * \\
(0.001)\end{array}$ & 446,739 \\
\hline Toilet papers & $\begin{array}{l}0.45^{* * *} \\
(0.008)\end{array}$ & $\begin{array}{c}0.45^{* * *} \\
(0.009)\end{array}$ & $\begin{array}{c}0.14^{* * *} \\
(0.001)\end{array}$ & 920,896 & $\begin{array}{c}0.20 * * * \\
(0.007)\end{array}$ & $\begin{array}{c}0.20 * * * \\
(0.006)\end{array}$ & $\begin{array}{c}0.01^{* * *} \\
(0.002)\end{array}$ & 229,076 \\
\hline $\begin{array}{l}\text { Dummies for } \\
\text { weeks } \\
\text { Dummies for } \\
\text { product-store } \\
\text { Dummies for sub- } \\
\text { categories-store } \\
\text { Dummies for sub- } \\
\text { categories-store- } \\
\text { weeks }\end{array}$ & $\sqrt{ }$ & $\sqrt{ }$ & $\begin{array}{l}\sqrt{ } \\
\sqrt{ }\end{array}$ & & $\sqrt{ }$ & $\sqrt{ }$ & $\begin{array}{l}\sqrt{ } \\
\sqrt{ }\end{array}$ & \\
\hline
\end{tabular}

$\underline{\text { Notes }}$

In the table, we report the coefficient estimates of a 9-ending dummy in OLS regressions with fixed effects, where the dependent variable is the log of the prices. In columns (1)-(3), we report the results when we estimate the regression using data on regular prices only. In columns (4)-(6), we report the results when we estimate the regression using data on sale prices only. We use Dominick's sale dummy indicator to identify sale prices. In columns (1) and (4), the regression includes controls for weeks and for subcategories-store. In columns (2) and (5), the regression includes controls for subcategoriesstores-weeks. In columns (3) and (6), the regression includes dummies for weeks and for product-store. We could not estimate a regression for sale prices in the Cigarettes' category because there are only 21 observations on sale prices in that category and all of them end with 9. In parentheses we report robust standard errors, clustered at the store level.

$* p<10 \%$, ** $p<5 \%$, *** $p<1 \%$. 
Table 8. Average 9-Ending and 0-Ending Prices, and Percentage Difference between Them, Dominick’s, September 14, 1989-May 8, 1997

\begin{tabular}{|c|c|c|c|}
\hline Category & $\begin{array}{l}\text { (1) } \\
\text { 9-Ending }\end{array}$ & $\begin{array}{c}\text { (2) } \\
\text { 0-Ending }\end{array}$ & $\begin{array}{c}(3) \\
\% \text { Difference }\end{array}$ \\
\hline Analgesics & 5.33 & 4.21 & $10.24 \%$ \\
\hline Bath Soaps & 3.15 & 4.54 & $-15.92 \%$ \\
\hline Beer & 5.68 & 4.67 & $8.52 \%$ \\
\hline Bottled Juices & 2.27 & 2.21 & $1.12 \%$ \\
\hline Cereal & 3.08 & 2.85 & $3.37 \%$ \\
\hline Cheese & 2.53 & 2.11 & $7.88 \%$ \\
\hline Cigarettes & 11.93 & 5.64 & $32.54 \%$ \\
\hline Cookies & 2.06 & 2.36 & $-5.99 \%$ \\
\hline Crackers & 2.08 & 2.14 & $-1.24 \%$ \\
\hline Canned Soups & 1.21 & 1.36 & $-5.15 \%$ \\
\hline Dish Detergents & 2.36 & 2.30 & $1.14 \%$ \\
\hline Front-End-Candies & 0.74 & 0.55 & $13.00 \%$ \\
\hline Frozen Dinners & 2.33 & 3.07 & $-11.98 \%$ \\
\hline Frozen Entrees & 2.34 & 3.47 & $-17.10 \%$ \\
\hline Frozen Juices & 1.32 & 1.82 & $-13.83 \%$ \\
\hline Fabric Softeners & 2.88 & 2.58 & $4.77 \%$ \\
\hline Grooming products & 3.02 & 1.89 & $20.26 \%$ \\
\hline Laundry Detergents & 5.76 & 5.33 & $3.39 \%$ \\
\hline Oatmeal & 2.65 & 2.36 & $5.00 \%$ \\
\hline Paper Towels & 1.69 & 1.71 & $-0.40 \%$ \\
\hline Refrigerated Juices & 2.281 & 2.280 & $0.02 \%$ \\
\hline Soft Drinks & 2.53 & 1.53 & $21.84 \%$ \\
\hline Shampoos & 3.00 & 2.19 & $13.67 \%$ \\
\hline Snack Crackers & 2.20 & 2.20 & $0.00 \%$ \\
\hline Soaps & 2.74 & 2.18 & $9.97 \%$ \\
\hline Toothbrushes & 2.21 & 1.85 & $7.72 \%$ \\
\hline Tuna & 1.99 & 1.48 & $12.93 \%$ \\
\hline Toothpastes & 2.53 & 2.07 & $8.78 \%$ \\
\hline Toilet papers & 2.51 & 1.24 & $30.63 \%$ \\
\hline $\begin{array}{l}\text { Average of the Positive \% } \\
\text { Differences }\end{array}$ & & & $10.84 \%$ \\
\hline
\end{tabular}

Notes

In columns (1) and (2), we report the average 9-ending and 0-ending prices, respectively, in each one of the 29 Dominick's product categories, calculated over all stores and weeks. In column (3), we report the percentage difference between the average 9-ending and the average 0-ending prices computed as a log-difference. The 20 product categories with positive values in column (3) are indicated in italic boldface. All the differences are statistically significant based on the MannWhitney test with $p<0.01$. 
Table 9. Regression Analyses of the Percentage Difference between 9-Ending and 0-Ending Prices, Dominick’s, September 14, 1989-May 8, 1997

\begin{tabular}{|c|c|c|c|c|}
\hline & $(1)$ & $(2)$ & (3) & $N$ \\
\hline Analgesics & $0.18(0.009)^{* * *}$ & $0.18(0.009)^{* * *}$ & $0.15(0.003)^{* * *}$ & $2,627,640$ \\
\hline Bath Soaps & $-0.16(0.035)^{* * *}$ & $-0.14(0.035)^{* * *}$ & $0.31(0.002)^{* * *}$ & 382,106 \\
\hline Beer & $0.33(0.018)^{* * *}$ & $0.31(0.018)^{* * *}$ & $0.22(0.003)^{* * *}$ & $1,889,570$ \\
\hline Bottled Juices & $0.08(0.011)^{* * *}$ & $0.08(0.011)^{* * *}$ & $0.02(0.001)^{* * *}$ & $2,400,064$ \\
\hline Cereal & $0.05(0.002)^{* * *}$ & $0.05(0.003)^{* * *}$ & $0.05(0.001)^{* * *}$ & $2,061,159$ \\
\hline Cheese & $0.23(0.003)^{* * *}$ & $0.18(0.002)^{* * *}$ & $0.17(0.001)^{* * *}$ & $4,426,654$ \\
\hline Cigarettes & $1.10(0.080)^{* * *}$ & $0.03(0.035)^{* * *}$ & $0.55(0.003)^{* * *}$ & 452,873 \\
\hline Cookies & $-0.10(0.013)^{* * *}$ & $-0.05(0.012)^{* * *}$ & $-0.04(0.001)^{* * *}$ & $5,758,138$ \\
\hline Crackers & $0.01(0.005)$ & $0.01(0.006)$ & $-0.00(0.001)^{* *}$ & $1,491,464$ \\
\hline Canned Soups & $-0.00(0.015)$ & $-0.02(0.015)$ & $-0.03(0.001)^{* * *}$ & $1,858,854$ \\
\hline Dish Detergents & $0.07(0.006)^{* * *}$ & $0.05(0.006)^{* * *}$ & $0.09(0.002)^{* * *}$ & $1,483,456$ \\
\hline Front-End-Candies & $0.35(0.003)^{* * *}$ & $0.34(0.003)^{* * *}$ & $0.22(0.001)^{* * *}$ & $2,800,489$ \\
\hline Frozen Dinners & $-0.25(0.08)^{* * *}$ & $-0.29(0.09)^{* * *}$ & $-0.06(0.001)^{* * *}$ & $1,157,152$ \\
\hline Frozen Entrees & $-0.27(0.012)^{* * *}$ & $-0.29(0.012)^{* * *}$ & $-0.28(0.000)^{* * *}$ & $4,962,968$ \\
\hline Frozen Juices & $-0.23(0.010)^{* * *}$ & $-0.24(0.011)^{* * *}$ & $-0.17(0.001)^{* * *}$ & $1,253,120$ \\
\hline Fabric Softeners & $0.02(0.006)^{* * *}$ & $0.01(0.006)$ & $0.02(0.001)^{* * *}$ & $1,418,673$ \\
\hline Grooming products & $0.44(0.002)^{* * *}$ & $0.34(0.001)^{* * *}$ & $0.31(0.001)^{* * *}$ & $3,665,407$ \\
\hline Laundry Detergents & $0.09(0.012)^{* * *}$ & $0.09(0.010)^{* * *}$ & $0.11(0.000)^{* * *}$ & $2,545,027$ \\
\hline Oatmeal & $0.11(0.007)^{* * *}$ & $0.10(0.007)^{* * *}$ & $0.07(0.001)^{* * *}$ & 534,846 \\
\hline Paper Towels & $0.01(0.015)$ & $-0.02(0.016)$ & $-0.03(0.003)^{* * *}$ & 496,075 \\
\hline Refrigerated Juices & $0.02(0.006)^{* * *}$ & $0.02(0.006)^{* * *}$ & $0.06(0.001)^{* * *}$ & $1,301,869$ \\
\hline Soft Drinks & $0.48(0.013)^{* * *}$ & $0.11(0.013)^{* * *}$ & $0.09(0.001)^{* * *}$ & $9,342,891$ \\
\hline Shampoos & $0.26(0.007)^{* * *}$ & $0.21(0.005)^{* * *}$ & $0.28(0.001)^{* * *}$ & $4,383,314$ \\
\hline Snack Crackers & $0.08(0.010)^{* * *}$ & $0.09(0.010)^{* * *}$ & $0.06(0.001)^{* * *}$ & $2,635,531$ \\
\hline Soaps & $0.14(0.007)^{* * *}$ & $0.14(0.006)^{* * *}$ & $0.17(0.002)^{* * *}$ & $1,188,833$ \\
\hline Toothbrushes & $0.15(0.006)^{* * *}$ & $0.16(0.006)^{* * *}$ & $0.18(0.001)^{* * *}$ & $1,392,950$ \\
\hline Tuna & $0.27(0.004)^{* * *}$ & $0.27(0.005)^{* * *}$ & $-0.01(0.001)^{* * *}$ & $1,250,726$ \\
\hline Toothpastes & $0.19(0.006)^{* * *}$ & $0.19(0.006)^{* * *}$ & $0.15(0.001)^{* * *}$ & $1,973,223$ \\
\hline Toilet papers & $0.66(0.018)^{* * *}$ & $0.65(0.019)^{* * *}$ & $0.14(0.002)^{* * *}$ & 662,257 \\
\hline Dummies for weeks & $\sqrt{ }$ & & $\sqrt{ }$ & \\
\hline $\begin{array}{l}\text { Dummies for product- } \\
\text { store }\end{array}$ & & & $\sqrt{ }$ & \\
\hline $\begin{array}{l}\text { Dummies for sub- } \\
\text { categories-store }\end{array}$ & $\sqrt{ }$ & & & \\
\hline $\begin{array}{l}\text { Dummies for sub- } \\
\text { categories-store-weeks }\end{array}$ & & $\sqrt{ }$ & & \\
\hline
\end{tabular}

$\underline{\text { Notes }}$

In the table, we report the coefficient estimates of a 9-ending dummy in OLS regressions with fixed effects, where the dependent variable is the log of the prices. The sample includes only 9-ending and 0 -ending prices. The 9-ending dummy equals 1 if the price ends with 9, and 0 if the price ends with 0 . In column (1), the regression includes controls for weeks and for subcategories-store. In column (2), the regression includes controls for subcategories-stores-weeks. In column (3), the regression includes dummies for weeks and for product-store. In parentheses, we report robust standard errors, clustered at the store level. $* p<10 \%, * * p<5 \%, * * * p<1 \%$. 
Table 10. Average Truncated 9-Ending and non 9-Ending Prices, and the Percentage Differences between Them, Dominick’s, September 14, 1989-May 8, 1997

\begin{tabular}{|c|c|c|c|}
\hline Category & $\begin{array}{l}\text { (1) } \\
\text { 9-Ending }\end{array}$ & $\begin{array}{c}\text { (2) } \\
\text { Non 9-Ending }\end{array}$ & $\begin{array}{c}(3) \\
\text { \% Difference }\end{array}$ \\
\hline Analgesics & 5.24 & 4.26 & $20.71 \%$ \\
\hline Bath Soaps & 3.06 & 3.21 & $-4.79 \%$ \\
\hline Beer & 5.59 & 5.79 & $-3.52 \%$ \\
\hline Bottled Juices & 2.18 & 2.17 & $0.46 \%$ \\
\hline Cereal & 2.99 & 3.10 & $-3.61 \%$ \\
\hline Cheese & 2.50 & 2.23 & $11.43 \%$ \\
\hline Cigarettes & 11.84 & 6.81 & $55.31 \%$ \\
\hline Cookies & 1.97 & 2.18 & $-10.13 \%$ \\
\hline Crackers & 1.99 & 1.86 & $6.76 \%$ \\
\hline Canned Soups & 1.12 & 1.05 & $6.45 \%$ \\
\hline Dish Detergents & 2.27 & 2.26 & $0.44 \%$ \\
\hline Front-End-Candies & 0.65 & 0.50 & $26.24 \%$ \\
\hline Frozen Dinners & 2.24 & 2.38 & $-6.06 \%$ \\
\hline Frozen Entrees & 2.25 & 2.28 & $-1.32 \%$ \\
\hline Frozen Juices & 1.23 & 1.40 & $-12.95 \%$ \\
\hline Fabric Softeners & 2.79 & 2.69 & $3.65 \%$ \\
\hline Grooming products & 2.93 & 2.38 & $20.79 \%$ \\
\hline Laundry Detergents & 5.67 & 5.06 & $11.38 \%$ \\
\hline Oatmeal & 2.56 & 2.61 & $-1.93 \%$ \\
\hline Paper Towels & 1.60 & 1.26 & $23.89 \%$ \\
\hline Refrigerated Juices & 2.19 & 2.14 & $2.31 \%$ \\
\hline Soft Drinks & 2.44 & 1.40 & $55.55 \%$ \\
\hline Shampoos & 2.91 & 2.41 & $18.85 \%$ \\
\hline Snack Crackers & 2.11 & 2.09 & $0.95 \%$ \\
\hline Soaps & 2.65 & 2.07 & $24.70 \%$ \\
\hline Toothbrushes & 2.12 & 2.04 & $3.85 \%$ \\
\hline Tuna & 1.90 & 1.58 & $18.44 \%$ \\
\hline Toothpastes & 2.44 & 2.21 & $9.90 \%$ \\
\hline Toilet papers & 2.42 & 1.60 & $41.38 \%$ \\
\hline $\begin{array}{l}\text { Average of the Positive \% } \\
\text { Differences }\end{array}$ & & & 17.31 \\
\hline
\end{tabular}

Notes

Columns (1) and (2) report the average truncated 9-ending and non 9-ending prices, respectively, in each of the 29 Dominick's product categories, calculated over all stores and weeks. Column (3) reports the percentage difference between them computed as a log-difference. The 21 product categories with positive values in column (3) are indicated in italic boldface. All the differences are statistically significant based on the Mann-Whitney test, with $p<0.01$. 
Table 11. Regression Analyses of the Percentage Difference between Truncated 9-Ending and Non 9Ending Prices, Dominick’s, September 14, 1989-May 8, 1997

\begin{tabular}{|c|c|c|c|c|}
\hline & (1) & $(2)$ & (3) & $N$ \\
\hline Analgesics & $0.12(0.005)^{* * *}$ & $0.12(0.005)^{* * *}$ & $0.14(0.001)^{* * *}$ & $3,040,159$ \\
\hline Bath Soaps & $-0.00(0.010)$ & $0.00(0.009)$ & $0.09(0.001)^{* * *}$ & 418,096 \\
\hline Beer & $0.02(0.010)$ & $0.02(0.009)^{* *}$ & $-0.03(0.001)^{* * *}$ & $1,966,147$ \\
\hline Bottled Juices & $0.00(0.003)$ & $0.00(0.003)$ & $-0.00(0.000)^{* * *}$ & $4,325,024$ \\
\hline Cereal & $-0.04(0.001)^{* * *}$ & $-0.04(0.001)^{* * *}$ & $-0.01(0.000)^{* * *}$ & $4,707,772$ \\
\hline Cheese & $0.08(0.002)^{* * *}$ & $0.06(0.002)^{* * *}$ & $0.12(0.003)^{* * *}$ & $6,752,325$ \\
\hline Cigarettes & $0.58(0.059)^{* * *}$ & $0.00(0.006)$ & $0.26(0.001)^{* * *}$ & $1,801,443$ \\
\hline Cookies & $-0.12(0.003)^{* * *}$ & $-0.03(0.002)^{* * *}$ & $-0.03(0.000)^{* * *}$ & $7,568,350$ \\
\hline Crackers & $0.04(0.001)^{* * *}$ & $0.05(0.001)^{* * *}$ & $0.01(0.000)^{* * *}$ & $2,228,268$ \\
\hline Canned Soups & $0.05(0.006)^{* * *}$ & $0.04(0.006)^{* * *}$ & $0.01(0.000)^{* * *}$ & $5,504,492$ \\
\hline Dish Detergents & $0.01(0.007)$ & $0.01(0.004)^{* *}$ & $-0.01(0.000)^{* * *}$ & $2,164,793$ \\
\hline Front-End-Candies & $0.33(0.002)^{* * *}$ & $0.31(0.003)^{* * *}$ & $0.16(0.000)^{* * *}$ & $4,436,801$ \\
\hline Frozen Dinners & $-0.04(0.007)^{* * *}$ & $-0.04(0.007)^{* * *}$ & $0.02(0.000)^{* * *}$ & $1,654,053$ \\
\hline Frozen Entrees & $0.03(0.005)^{* * *}$ & $0.03(0.005)^{* * *}$ & $-0.02(0.000)^{* * *}$ & $7,172,075$ \\
\hline Frozen Juices & $-0.12(0.003)^{* * *}$ & $-0.12(0.003)^{* * *}$ & $-0.10(0.000)^{* * *}$ & 351,519 \\
\hline Fabric Softeners & $-0.05(0.003)^{* * *}$ & $-0.06(0.003)^{* * *}$ & $-0.01(0.000)^{* * *}$ & $2,278,536$ \\
\hline Grooming products & $0.19(0.002)^{* * *}$ & $0.14(0.002)^{* * *}$ & $0.15(0.000)^{* * *}$ & $4,065,687$ \\
\hline Laundry Detergents & $0.08(0.003)^{* * *}$ & $0.12(0.002)^{* * *}$ & $0.11(0.001)^{* * *}$ & $3,277,442$ \\
\hline Oatmeal & $-0.04(0.006)^{* * *}$ & $-0.03(0.006)^{* * *}$ & $-0.01(0.000)^{* * *}$ & 981,037 \\
\hline Paper Towels & $0.10(0.001)^{* * *}$ & $0.09(0.001)^{* * *}$ & $-0.00(0.001)^{* *}$ & 940,757 \\
\hline Refrigerated Juices & $0.04(0.004)^{* * *}$ & $0.04(0.004)^{* * *}$ & $0.04(0.001)^{* * *}$ & $2,166,755$ \\
\hline Soft Drinks & $0.69(0.010)^{* * *}$ & $0.27(0.005)^{* * *}$ & $0.27(0.000)^{* * *}$ & $10,741,681$ \\
\hline Shampoos & $0.14(0.012)^{* * *}$ & $0.09(0.009)^{* * *}$ & $0.09(0.000)^{* * *}$ & $4,666,564$ \\
\hline Snack Crackers & $0.00(0.005)$ & $0.01(0.004)$ & $0.02(0.000)^{* * *}$ & $3,487,548$ \\
\hline Soaps & $0.13(0.004)^{* * *}$ & $0.12(0.004)^{* * *}$ & $0.09(0.001)^{* * *}$ & $1,835,196$ \\
\hline Toothbrushes & $-0.06(0.005)^{* * *}$ & $-0.04(0.005)^{* * *}$ & $-0.01(0.000)^{* * *}$ & $1,772,158$ \\
\hline Tuna & $0.16(0.003)^{* * *}$ & $0.16(0.003)^{* * *}$ & $0.07(0.001)^{* * *}$ & $2,382,983$ \\
\hline Toothpastes & $-0.02(0.004)^{* * *}$ & $-0.01(0.004)^{* * *}$ & $-0.03(0.000)^{* * *}$ & $2,981,532$ \\
\hline Toilet papers & $0.39(0.008)^{* * *}$ & $0.39(0.008)^{* * *}$ & $0.07(0.001)^{* * *}$ & $1,149,972$ \\
\hline Dummies for weeks & $\sqrt{ }$ & & $\sqrt{ }$ & \\
\hline $\begin{array}{l}\text { Dummies for product- } \\
\text { store }\end{array}$ & & & $\sqrt{ }$ & \\
\hline $\begin{array}{l}\text { Dummies for sub- } \\
\text { categories-store }\end{array}$ & $\sqrt{ }$ & & & \\
\hline $\begin{array}{l}\text { Dummies for sub- } \\
\text { categories-store-weeks }\end{array}$ & & $\sqrt{ }$ & & \\
\hline
\end{tabular}

Notes

The table reports the coefficients of a 9-ending dummy in OLS regressions with fixed effects, where the dependent variable is the log of the prices. The sample includes truncated 9-ending and non 9-ending prices. In column (1), the regression includes controls for weeks and for subcategories-store. In column (2), the regression includes controls for subcategories-stores-weeks. In column (3), the regression includes dummies for weeks and for product-store. Robust standard errors, clustered at the store level are reported in parentheses. ${ }^{* * *} p<1 \%$. ${ }^{* *} p<5 \%$ 
Table 12. Regression Analyses of the Level Difference between 9-Ending and Non 9-Ending Prices, Dominick’s, September 14, 1989-May 8, 1997

\begin{tabular}{|c|c|c|c|c|}
\hline & (1) & (2) & (3) & $N$ \\
\hline Analgesics & $0.64(0.025)^{* * *}$ & $0.65(0.026)^{* * *}$ & $0.72(0.004) * * *$ & $3,040,172$ \\
\hline Bath Soaps & $-0.19(0.49)^{* * *}$ & $-0.16(0.47)^{* * *}$ & $0.33(0.004)^{* * *}$ & 418,097 \\
\hline Beer & $-0.07(0.040)^{*}$ & $0.00(0.039)$ & $-0.22(0.006)^{* * *}$ & $1,966,148$ \\
\hline Bottled Juices & $0.06(0.007)^{* * *}$ & $0.06(0.007)^{* * *}$ & $0.04(0.001)^{* * *}$ & $4,325,024$ \\
\hline Cereal & $-0.06(0.003)^{* * *}$ & $-0.06(0.003)^{* * *}$ & $0.03(0.001)^{* * *}$ & $4,707,776$ \\
\hline Cheese & $0.25(0.004)^{* * *}$ & $0.21(0.003)^{* * *}$ & $0.33(0.001)^{* * *}$ & $6,752,326$ \\
\hline Cigarettes & $4.83(0.472)^{* * *}$ & $-0.02(0.036)$ & $2.16(0.010)^{* * *}$ & $1,801,444$ \\
\hline Cookies & $-0.20(0.037)^{* * *}$ & $-0.02(0.005)^{* * *}$ & $-0.00(0.000)^{* * *}$ & $7,568,352$ \\
\hline Crackers & $0.13(0.003)^{* * *}$ & $0.14(0.002)^{* * *}$ & $0.04(0.001)^{* * *}$ & $2,228,268$ \\
\hline Canned Soups & $0.10(0.006)^{* * *}$ & $0.10(0.006)^{* * *}$ & $0.06(0.000)^{* * *}$ & $5,504,492$ \\
\hline Dish Detergents & $0.09(0.014)^{* * *}$ & $0.10(0.010)^{* * *}$ & $0.05(0.001)^{* * *}$ & $2,164,793$ \\
\hline Front-End-Candies & $0.23(0.002)^{* * *}$ & $0.22(0.002)^{* * *}$ & $0.13(0.000)^{* * *}$ & $4,437,054$ \\
\hline Frozen Dinners & $-0.06(0.017)^{* * *}$ & $-0.06(0.017)^{* * *}$ & $0.04(0.001)^{* * *}$ & $1,654,053$ \\
\hline Frozen Entrees & $0.02(0.015)$ & $0.01(0.016)$ & $-0.08(0.001)^{* * *}$ & $7,172,075$ \\
\hline Frozen Juices & $-0.12(0.004)^{* * *}$ & $-0.12(0.004)^{* * *}$ & $-0.10(0.001)^{* * *}$ & $2,368,157$ \\
\hline Fabric Softeners & $0.07(0.008)^{* * *}$ & $0.06(0.007)^{* * *}$ & $0.16(0.002)^{* * *}$ & $2,278,995$ \\
\hline Grooming products & $0.58(0.008)^{* * *}$ & $0.38(0.006)^{* * *}$ & $0.42(0.001)^{* * *}$ & $4,065,689$ \\
\hline Laundry Detergents & $0.62(0.015)^{* * *}$ & $0.86(0.011)^{* * *}$ & $0.77(0.004)^{* * *}$ & $3,277,444$ \\
\hline Oatmeal & $-0.04(0.014)^{* * *}$ & $-0.03(0.001)^{*}$ & $0.02(0.001)^{* * *}$ & 981,037 \\
\hline Paper Towels & $0.43(0.021)^{* * *}$ & $0.42(0.021)^{* * *}$ & $0.28(0.003)^{* * *}$ & 940,757 \\
\hline Refrigerated Juices & $0.11(0.008)^{* * *}$ & $0.11(0.008)^{* * *}$ & $0.12(0.001)^{* * *}$ & $2,166,755$ \\
\hline Soft Drinks & $1.08(0.13)^{* * *}$ & $0.35(0.007)^{* * *}$ & $0.41(0.001)^{* * *}$ & $10,741,742$ \\
\hline Shampoos & $0.52(0.032)^{* * *}$ & $0.37(0.024)^{* * *}$ & $0.30(0.001)^{* * *}$ & $4,666,565$ \\
\hline Snack Crackers & $0.03(0.008)^{* * *}$ & $0.04(0.008)^{* * *}$ & $0.09(0.001)^{* * *}$ & $3,487,564$ \\
\hline Soaps & $0.49(0.012)^{* * *}$ & $0.49(0.012)^{* * *}$ & $0.43(0.002)^{* * *}$ & $1,835,196$ \\
\hline Toothbrushes & $-0.03(0.008)^{* * *}$ & $-0.01(0.008)$ & $0.05(0.001)^{* * *}$ & $1,772,158$ \\
\hline Tuna & $0.47(0.005)^{* * *}$ & $0.37(0.005)^{* * *}$ & $0.21(0.001)^{* * *}$ & $2,382,983$ \\
\hline Toothpastes & $0.05(0.009)^{* * *}$ & $0.06(0.008)^{* * *}$ & $-0.03(0.001)^{* * *}$ & $2,981,532$ \\
\hline Toilet papers & $0.75(0.004)^{* * *}$ & $0.75(0.004)^{* * *}$ & $0.26(0.002)^{* * *}$ & $1,149,972$ \\
\hline Dummies for weeks & $\sqrt{ }$ & & $\sqrt{ }$ & \\
\hline $\begin{array}{l}\text { Dummies for product- } \\
\text { store }\end{array}$ & & & $\sqrt{ }$ & \\
\hline $\begin{array}{l}\text { Dummies for sub- } \\
\text { categories-store }\end{array}$ & $\sqrt{ }$ & & & \\
\hline $\begin{array}{l}\text { Dummies for sub- } \\
\text { categories-store-weeks }\end{array}$ & & $\sqrt{ }$ & & \\
\hline
\end{tabular}

$\underline{\text { Notes }}$

In the table, we report the coefficient estimates of a 9-ending dummy in OLS regressions with fixed effects, where the dependent variables are the prices. The 9-ending dummy equals 1 if the price ends with 9 , and 0 if the price ends with any other digit. In column (1), the regression includes controls for weeks and for subcategories-store. In column (2), the regression includes controls for subcategories-stores-weeks. In column (3), the regression includes dummies for weeks and for product-store. In parentheses, we report robust standard errors, clustered at the store level. ${ }^{*} p<10 \%,{ }^{* *} p<5 \%,{ }^{* * *} p<1 \%$. 
Table 13. Average 9-Ending and Non 9-Ending Prices, and Percentage Difference between Them, Outliers Excluded, Dominick’s, September 14, 1989-May 8, 1997

\begin{tabular}{|c|c|c|c|}
\hline Category & $\begin{array}{l}\text { (1) } \\
\text { 9-Ending }\end{array}$ & $\begin{array}{c}\text { (2) } \\
\text { Non 9-Ending }\end{array}$ & $\begin{array}{c}\text { (3) } \\
\text { \% Difference }\end{array}$ \\
\hline Analgesics & 4.95 & 4.16 & $7.55 \%$ \\
\hline Bath Soaps & 2.88 & 2.60 & $4.40 \%$ \\
\hline Beer & 1.58 & 1.54 & $1.14 \%$ \\
\hline Bottled Juices & 2.13 & 2.12 & $0.20 \%$ \\
\hline Cereal & 3.08 & 3.17 & $-1.20 \%$ \\
\hline Cheese & 2.34 & 2.16 & $3.52 \%$ \\
\hline Cigarettes & 11.92 & 6.80 & $24.39 \%$ \\
\hline Cookies & 0.67 & 0.74 & $-4.10 \%$ \\
\hline Crackers & 2.05 & 1.87 & $3.91 \%$ \\
\hline Canned Soups & 1.16 & 1.05 & $4.37 \%$ \\
\hline Dish Detergents & 0.74 & 0.75 & $-0.58 \%$ \\
\hline Front-End-Candies & 0.74 & 0.51 & $16.18 \%$ \\
\hline Frozen Dinners & 2.29 & 2.31 & $-0.46 \%$ \\
\hline Frozen Entrees & 2.25 & 2.03 & $4.56 \%$ \\
\hline Frozen Juices & 1.31 & 1.39 & $-2.48 \%$ \\
\hline Fabric Softeners & 2.58 & 2.63 & $-0.75 \%$ \\
\hline Grooming products & 2.78 & 2.31 & $8.07 \%$ \\
\hline Laundry Detergents & 4.72 & 5.14 & $3.70 \%$ \\
\hline Oatmeal & 2.68 & 2.69 & $-0.09 \%$ \\
\hline Paper Towels & 1.28 & 1.22 & $1.93 \%$ \\
\hline Refrigerated Juices & 0.72 & 0.64 & $5.41 \%$ \\
\hline Soft Drinks & 2.16 & 1.30 & $22.13 \%$ \\
\hline Shampoos & 2.75 & 2.39 & $6.15 \%$ \\
\hline Snack Crackers & 2.20 & 2.14 & $1.15 \%$ \\
\hline Soaps & 2.33 & 2.07 & $5.05 \%$ \\
\hline Toothbrushes & 2.13 & 2.01 & $2.54 \%$ \\
\hline Tuna & 1.80 & 1.52 & $7.34 \%$ \\
\hline Toothpastes & 0.84 & 0.79 & $2.80 \%$ \\
\hline Toilet papers & 2.10 & 1.55 & $13.21 \%$ \\
\hline $\begin{array}{l}\text { Average of the Positive \% } \\
\text { Differences }\end{array}$ & & & $15.96 \%$ \\
\hline
\end{tabular}

$\underline{\text { Notes }}$

In columns (1) and (2), we report the average 9-ending and non 9-ending prices, respectively, in each one of Dominick's 29 product categories, calculated over all stores and weeks. In column (3), we report the percentage difference between them computed as a log-difference. For each product category, we exclude from the sample the observations that are more than two standard deviations away from the category mean. The 22 product categories with positive values in column (3) are indicated in italic boldface. All the differences are statistically significant based on the Mann-Whitney test with $p<0.01$. 
Table 14. Regression Analysis of the Percentage Difference between the 9-Ending and Non 9-Ending Prices, Outliers Excluded, Dominick’s, September 14, 1989-May 8, 1997

\begin{tabular}{|c|c|c|c|c|}
\hline & (1) & (2) & (3) & $N$ \\
\hline Analgesics & $0.11(0.004)^{* * *}$ & $0.11(0.004)^{* * *}$ & $0.12(0.001)^{* * *}$ & $2,893,605$ \\
\hline Bath Soaps & $0.10(0.005)^{* * *}$ & $0.10(0.004)^{* * *}$ & $0.11(0.001)^{* * *}$ & 392,621 \\
\hline Beer & $0.06(0.001)^{* * *}$ & $0.06(0.001)^{* * *}$ & $-0.02(0.001)^{* * *}$ & $1,858,635$ \\
\hline Bottled Juices & $0.02(0.002)^{* * *}$ & $0.01(0.002)^{* * *}$ & $0.01(0.000)^{* * *}$ & $4,166,948$ \\
\hline Cereal & $-0.03(0.001)^{* * *}$ & $-0.03(0.001)^{* * *}$ & $0.01(0.000)^{* * *}$ & $4,478,505$ \\
\hline Cheese & $0.08(0.002)^{* * *}$ & $0.06(0.001)^{* * *}$ & $-0.03(0.001)^{* * *}$ & $6,487,618$ \\
\hline Cigarettes & $0.60(0.006)^{* * *}$ & $0.02(0.005)^{* * *}$ & $0.28(0.001)^{* * *}$ & $1,796,262$ \\
\hline Cookies & $-0.10(0.002)^{* * *}$ & $0.00(0.001)$ & $0.01(0.000)^{* * *}$ & $7,308,003$ \\
\hline Crackers & $0.07(0.001)^{* * *}$ & $0.07(0.001)^{* * *}$ & $0.03(0.000)^{* * *}$ & $2,151,818$ \\
\hline Canned Soups & $0.09(0.005)^{* * *}$ & $0.09(0.005)^{* * *}$ & $0.06(0.000)^{* * *}$ & $5,345,950$ \\
\hline Dish Detergents & $0.00(0.007)$ & $0.01(0.005)^{* *}$ & $0.00(0.000)^{* * *}$ & $2,087,095$ \\
\hline Front-End-Candies & $0.40(0.002)^{* * *}$ & $0.39(0.002)^{* * *}$ & $0.24(0.000)^{* * *}$ & $4,397,689$ \\
\hline Frozen Dinners & $-0.00(0.007)$ & $0.00(0.006)$ & $0.07(0.000)^{* * *}$ & $1,617,178$ \\
\hline Frozen Entrees & $0.11(0.003)^{* * *}$ & $0.12(0.003)^{* * *}$ & $0.08(0.000)^{* * *}$ & $6,832,117$ \\
\hline Frozen Juices & $-0.06(0.002)^{* * *}$ & $-0.07(0.002)^{* * *}$ & $-0.05(0.000)^{* * *}$ & $2,319,924$ \\
\hline Fabric Softeners & $-0.07(0.003)^{* * *}$ & $-0.07(0.004)^{* * *}$ & $-0.01(0.000)^{* * *}$ & $2,161,634$ \\
\hline Grooming products & $0.19(0.003)^{* * *}$ & $0.15(0.003)^{* * *}$ & $0.16(0.000)^{* * *}$ & $3,872,011$ \\
\hline Laundry Detergents & $0.07(0.003)^{* * *}$ & $0.09(0.002)^{* * *}$ & $0.08(0.001)^{* * *}$ & $3,087,133$ \\
\hline Oatmeal & $-0.01(0.006)^{*}$ & $-0.01(0.006)$ & $0.01(0.000)^{* * *}$ & 926,918 \\
\hline Paper Towels & $0.04(0.007)^{* * *}$ & $0.04(0.008)^{* * *}$ & $-0.06(0.001)^{* * *}$ & 903,436 \\
\hline Refrigerated Juices & $0.10(0.003)^{* * *}$ & $0.10(0.003)^{* * *}$ & $0.09(0.001)^{* * *}$ & $2,064,972$ \\
\hline Soft Drinks & $0.63(0.009)^{* * *}$ & $0.31(0.005)^{* * *}$ & $0.28(0.000)^{* * *}$ & $1,0091,205$ \\
\hline Shampoos & $0.12(0.010)^{* * *}$ & $0.11(0.008)^{* * *}$ & $0.11(0.000)^{* * *}$ & $4,462,260$ \\
\hline Snack Crackers & $-0.00(0.002)^{* *}$ & $0.00(0.002)$ & $0.05(0.000)^{* * *}$ & $3,361,275$ \\
\hline Soaps & $0.08(0.003)^{* * *}$ & $0.07(0.002)^{* * *}$ & $0.04(0.000)^{* * *}$ & $1,722,143$ \\
\hline Toothbrushes & $-0.05(0.005)^{* * *}$ & $-0.04(0.005)^{* * *}$ & $0.02(0.000)^{* * *}$ & $1,713,069$ \\
\hline Tuna & $0.16(0.002)^{* * *}$ & $0.16(0.002)^{* * *}$ & $0.09(0.000)^{* * *}$ & $2,285,445$ \\
\hline Toothpastes & $-0.02(0.002)^{* * *}$ & $-0.02(0.002)^{* * *}$ & $-0.02(0.000)^{* * *}$ & $2,878,058$ \\
\hline Toilet papers & $0.36(0.007)^{* * *}$ & $0.35(0.007)^{* * *}$ & $0.08(0.001)^{* * *}$ & $1,091,805$ \\
\hline Dummies for weeks & $\sqrt{ }$ & & $\sqrt{ }$ & \\
\hline $\begin{array}{l}\text { Dummies for product- } \\
\text { store }\end{array}$ & & & $\sqrt{ }$ & \\
\hline $\begin{array}{l}\text { Dummies for sub- } \\
\text { categories-store }\end{array}$ & $\sqrt{ }$ & & & \\
\hline $\begin{array}{l}\text { Dummies for sub- } \\
\text { categories-store-weeks }\end{array}$ & & $\sqrt{ }$ & & \\
\hline
\end{tabular}

Notes

The table reports the coefficients of a 9-ending dummy in OLS regressions with fixed effects, where the dependent variable is the log of the prices. For each product category, we exclude from the sample the observations that are more than two standard deviations away from the category mean. In column (1), the regression includes controls for weeks and for subcategories-store. In column (2), the regression includes controls for subcategories-stores-weeks. In column (3), the regression includes dummies for weeks and for product-store. The estimated coefficients in the Oatmeal category in columns (1) and (2) look equal because of the rounding. Without rounding, only one of them is statistically significant. Robust standard errors, clustered at the store level are reported in parentheses. ${ }^{* * *} p<1 \%$. ${ }^{* *} p<5 \%$ 
Table 15. The Share of 9-Ending Prices by Product Categories, Sale Prices and Regular Prices, Using a Sale Filter, Dominick’s, September 14, 1989-May 8, 1997

\begin{tabular}{|c|c|c|c|}
\hline Category & $\begin{array}{c}\text { (1) } \\
\text { Sale Prices }\end{array}$ & $\begin{array}{c}\text { (2) } \\
\text { Regular Prices }\end{array}$ & $\begin{array}{c}\text { (3) } \\
\text { Difference }\end{array}$ \\
\hline Analgesics & $67.3 \%$ & $86.8 \%$ & $-19.5 \%$ \\
\hline Bath Soaps & $60.5 \%$ & $89.2 \%$ & $-28.7 \%$ \\
\hline Beer & $90.8 \%$ & $96.6 \%$ & $-5.8 \%$ \\
\hline Bottled Juices & $43.3 \%$ & $51.8 \%$ & $-8.5 \%$ \\
\hline Cereal & $38.7 \%$ & $39.7 \%$ & $-1.0 \%$ \\
\hline Cheese & $41.0 \%$ & $65.2 \%$ & $-24.2 \%$ \\
\hline Cigarettes & $4.3 \%$ & $16.5 \%$ & $-12.2 \%$ \\
\hline Cookies & $42.6 \%$ & $77.8 \%$ & $-35.2 \%$ \\
\hline Crackers & $34.3 \%$ & $68.3 \%$ & $-34.0 \%$ \\
\hline Canned Soups & $26.5 \%$ & $31.4 \%$ & $-4.9 \%$ \\
\hline Dish Detergents & $59.0 \%$ & $68.1 \%$ & $-9.1 \%$ \\
\hline Front-End-Candies & $20.5 \%$ & $40.1 \%$ & $-19.6 \%$ \\
\hline Frozen Dinners & $27.2 \%$ & $62.4 \%$ & $-35.2 \%$ \\
\hline Frozen Entrees & $29.3 \%$ & $64.2 \%$ & $-34.9 \%$ \\
\hline Frozen Juices & $48.1 \%$ & $46.1 \%$ & $2.0 \%$ \\
\hline Fabric Softeners & $56.9 \%$ & $59.6 \%$ & $-2.7 \%$ \\
\hline Grooming products & $56.5 \%$ & $88.8 \%$ & $-32.3 \%$ \\
\hline Laundry Detergents & $64.8 \%$ & $77.5 \%$ & $-12.7 \%$ \\
\hline Oatmeal & $36.8 \%$ & $53.7 \%$ & $-16.9 \%$ \\
\hline Paper Towels & $48.3 \%$ & $50.3 \%$ & $-2.0 \%$ \\
\hline Refrigerated Juices & $53.5 \%$ & $57.7 \%$ & $-4.2 \%$ \\
\hline Soft Drinks & $64.8 \%$ & $87.4 \%$ & $-22.6 \%$ \\
\hline Shampoos & $73.1 \%$ & $92.6 \%$ & $-19.5 \%$ \\
\hline Snack Crackers & $41.1 \%$ & $77.6 \%$ & $-36.5 \%$ \\
\hline Soaps & $43.7 \%$ & $64.7 \%$ & $-21.0 \%$ \\
\hline Toothbrushes & $69.6 \%$ & $78.1 \%$ & $-8.5 \%$ \\
\hline Tuna & $32.2 \%$ & $50.6 \%$ & $-18.4 \%$ \\
\hline Toothpastes & $62.8 \%$ & $63.9 \%$ & $-1.1 \%$ \\
\hline Toilet papers & $52.7 \%$ & $53.5 \%$ & $-0.8 \%$ \\
\hline $\begin{array}{l}\text { Average of the Negative } \\
\text { Differences }\end{array}$ & & & $-16.9 \%$ \\
\hline
\end{tabular}

$\underline{\text { Notes }}$

Here we identify sale prices using "Filter A" of Nakamura and Steinsson (2008). In column (1), we report the percentage of 9-ending prices among sale prices. In column (2), we report the percentage of 9 -ending prices among regular prices. In column (3), we report the difference between the percentage of 9 -ending prices in sale prices and in regular prices. All the differences are statistically significant based on the $z$-scores proportions test, $p<0.01$. 
Table 16. Regression Analysis of the Percentage Difference between 9-Ending and Non 9-Ending

Prices, Regular and Sale Prices, Using a Sale Filter, Dominick’s, September 14, 1989-May 8, 1997

\begin{tabular}{|c|c|c|c|c|c|c|c|c|}
\hline & \multicolumn{4}{|c|}{ Regular Prices } & \multicolumn{4}{|c|}{ S Sale Prices } \\
\hline & (1) & (2) & (3) & $N$ & (4) & (5) & (6) & $N$ \\
\hline Analgesics & $\begin{array}{c}0.13^{* * *} \\
(0.005)\end{array}$ & $\begin{array}{l}0.13^{* * *} \\
(0.005)\end{array}$ & $\begin{array}{c}0.15^{* * *} \\
(0.000)\end{array}$ & $2,924,303$ & $\begin{array}{c}0.00 \\
(0.003)\end{array}$ & $\begin{array}{c}0.01^{*} \\
(0.003)\end{array}$ & $\begin{array}{c}-0.01 * * * \\
(0.002)\end{array}$ & 115,869 \\
\hline Bath Soaps & $\begin{array}{l}-0.01 \\
(0.011)\end{array}$ & $\begin{array}{l}-0.01 \\
(0.010)\end{array}$ & $\begin{array}{c}0.11^{* * *} \\
(0.001)\end{array}$ & 405,439 & $\begin{array}{c}0.02 * * * \\
(0.008)\end{array}$ & $\begin{array}{c}0.03^{* * *} \\
(0.007)\end{array}$ & $\begin{array}{c}-0.04^{* * *} \\
(0.003)\end{array}$ & 12,658 \\
\hline Beer & $\begin{array}{c}0.02 \\
(0.010)\end{array}$ & $\begin{array}{l}0.02 * * \\
(0.010)\end{array}$ & $\begin{array}{c}-0.04 * * * \\
(0.001)\end{array}$ & $1,660,236$ & $\begin{array}{c}0.11^{* * *} \\
(0.010)\end{array}$ & $\begin{array}{c}0.09 * * * \\
(0.010)\end{array}$ & $\begin{array}{c}-0.03^{* * *} \\
(0.002)\end{array}$ & 305,912 \\
\hline Bottled Juices & $\begin{array}{c}0.02^{* * *} \\
(0.004)\end{array}$ & $\begin{array}{c}0.02^{* * *} \\
(0.003)\end{array}$ & $\begin{array}{c}0.02^{* * *} \\
(0.000)\end{array}$ & $3,753,608$ & $\begin{array}{c}0.06^{* * *} \\
(0.003)\end{array}$ & $\begin{array}{c}0.05^{* * *} \\
(0.003)\end{array}$ & $\begin{array}{c}-0.00 * * \\
(0.001)\end{array}$ & 571,416 \\
\hline Cereal & $\begin{array}{c}-0.02 * * * \\
(0.001)\end{array}$ & $\begin{array}{c}-0.02 * * * \\
(0.001)\end{array}$ & $\begin{array}{c}0.01 * * * \\
(0.000)\end{array}$ & $4,379,009$ & $\begin{array}{c}-0.01^{* * *} \\
(0.003)\end{array}$ & $\begin{array}{c}-0.02 * * * \\
(0.003)\end{array}$ & $\begin{array}{c}-0.03 * * * \\
(0.001)\end{array}$ & 328,767 \\
\hline Cheese & $\begin{array}{c}0.12^{* * *} \\
(0.002)\end{array}$ & $\begin{array}{c}0.08 * * * \\
(0.002)\end{array}$ & $\begin{array}{c}0.16^{* * *} \\
(0.000)\end{array}$ & $5,684,114$ & $\begin{array}{c}-0.01^{* * *} \\
(0.001)\end{array}$ & $\begin{array}{c}-0.01^{* * *} \\
(0.001)\end{array}$ & $\begin{array}{c}0.03^{* * *} \\
(0.001)\end{array}$ & $1,068,212$ \\
\hline Cigarettes & $\begin{array}{c}0.59 * * * \\
(0.058)\end{array}$ & $\begin{array}{c}0.02 * * * \\
(0.005)\end{array}$ & $\begin{array}{c}0.27 * * * \\
(0.001)\end{array}$ & $1,793,459$ & $\begin{array}{c}0.01 \\
(0.201)\end{array}$ & $\begin{array}{c}-0.05^{* * *} \\
(0.017)\end{array}$ & $\begin{array}{c}0.22 * * * \\
(0.019)\end{array}$ & 7,985 \\
\hline Cookies & $\begin{array}{c}-0.13^{* * *} \\
(0.003)\end{array}$ & $\begin{array}{c}-0.03^{* * *} \\
(0.003)\end{array}$ & $\begin{array}{c}-0.04^{* * *} \\
(0.000)\end{array}$ & $6,725,729$ & $\begin{array}{c}-0.06 * * * \\
(0.001)\end{array}$ & $\begin{array}{c}-0.03^{* * *} \\
(0.001)\end{array}$ & $\begin{array}{c}-0.03^{* * *} \\
(0.001)\end{array}$ & 842,623 \\
\hline Crackers & $\begin{array}{c}0.07 * * * \\
(0.002)\end{array}$ & $\begin{array}{c}0.07 * * * \\
(0.001)\end{array}$ & $\begin{array}{c}0.02 * * * \\
(0.000)\end{array}$ & $1,943,794$ & $\begin{array}{c}-0.08^{* * * *} \\
(0.002)\end{array}$ & $\begin{array}{c}-0.07^{* * *} \\
(0.001)\end{array}$ & $\begin{array}{c}-0.06 * * * \\
(0.001)\end{array}$ & 284,474 \\
\hline Canned Soups & $\begin{array}{c}0.07 * * * \\
(0.005)\end{array}$ & $\begin{array}{l}0.08 * * * \\
(0.005)\end{array}$ & $\begin{array}{c}0.06^{* * *} \\
(0.000)\end{array}$ & $5,018,750$ & $\begin{array}{c}0.12^{* * *} \\
(0.002)\end{array}$ & $\begin{array}{c}0.11^{* * *} \\
(0.002)\end{array}$ & $\begin{array}{c}0.01 * * * \\
(0.001)\end{array}$ & 485,742 \\
\hline Dish Detergents & $\begin{array}{c}0.03^{* * *} \\
(0.007)\end{array}$ & $\begin{array}{c}0.04^{* * *} \\
(0.004)\end{array}$ & $\begin{array}{c}0.02 * * * \\
(0.000)\end{array}$ & $1,973,399$ & $\begin{array}{c}-0.04 * * * \\
(0.003)\end{array}$ & $\begin{array}{c}0.05^{* * *} \\
(0.002)\end{array}$ & $\begin{array}{c}-0.04 * * * \\
(0.001)\end{array}$ & 191,394 \\
\hline $\begin{array}{l}\text { Front-End- } \\
\text { Candies }\end{array}$ & $\begin{array}{c}0.39 * * * \\
(0.002)\end{array}$ & $\begin{array}{c}0.38 * * * \\
(0.002)\end{array}$ & $\begin{array}{c}0.24^{* * *} \\
(0.000)\end{array}$ & $4,189,543$ & $\begin{array}{c}0.18^{* * *} \\
(0.003)\end{array}$ & $\begin{array}{c}0.20 * * * \\
(0.004)\end{array}$ & $\begin{array}{c}0.06^{* * *} \\
(0.001)\end{array}$ & 247,511 \\
\hline Frozen Dinners & $\begin{array}{c}-0.06 * * * \\
(0.006)\end{array}$ & $\begin{array}{c}-0.07 * * * \\
(0.007)\end{array}$ & $\begin{array}{l}-0.00 \\
(0.000)\end{array}$ & $1,391,236$ & $\begin{array}{c}0.07 * * * \\
(0.005)\end{array}$ & $\begin{array}{c}0.04^{* * *} \\
(0.006)\end{array}$ & $\begin{array}{c}0.01^{* * *} \\
(0.001)\end{array}$ & 262,817 \\
\hline Frozen Entrees & $\begin{array}{c}0.01 * * * \\
(0.005)\end{array}$ & $\begin{array}{c}0.005 \\
(0.005)\end{array}$ & $\begin{array}{c}-0.05^{* * * *} \\
(0.000)\end{array}$ & $6,289,007$ & $\begin{array}{l}0.01 * * \\
(0.003)\end{array}$ & $\begin{array}{l}-0.01^{*} \\
(0.004)\end{array}$ & $\begin{array}{c}0.00^{*} \\
(0.001)\end{array}$ & 883,068 \\
\hline Frozen Juices & $\begin{array}{c}-0.07 * * * \\
(0.003)\end{array}$ & $\begin{array}{c}-0.08^{* * *} \\
(0.003)\end{array}$ & $\begin{array}{c}-0.06^{* * *} \\
(0.000)\end{array}$ & $2,016,638$ & $\begin{array}{c}-0.07 * * * \\
(0.002)\end{array}$ & $\begin{array}{c}-0.09 * * * \\
(0.002)\end{array}$ & $\begin{array}{c}-0.02 * * * \\
(0.001)\end{array}$ & 351,519 \\
\hline $\begin{array}{l}\text { Fabric } \\
\text { Softeners }\end{array}$ & $\begin{array}{c}-0.04 * * * \\
(0.003)\end{array}$ & $\begin{array}{c}-0.05^{* * *} \\
(0.003)\end{array}$ & $\begin{array}{c}0.02 * * * \\
(0.001)\end{array}$ & $2,101,762$ & $\begin{array}{l}0.10^{* * *} \\
(0.003)\end{array}$ & $\begin{array}{c}0.15^{* * *} \\
(0.003)\end{array}$ & $\begin{array}{c}0.01 \\
(0.002)\end{array}$ & 177,233 \\
\hline $\begin{array}{l}\text { Grooming } \\
\text { products }\end{array}$ & $\begin{array}{c}0.19 * * * \\
(0.003)\end{array}$ & $\begin{array}{c}0.14^{* * *} \\
(0.002)\end{array}$ & $\begin{array}{c}0.16^{* * *} \\
(0.000)\end{array}$ & $3,806,684$ & $\begin{array}{c}0.18^{* * *} \\
(0.004)\end{array}$ & $\begin{array}{c}0.08^{* * *} \\
(0.002)\end{array}$ & $\begin{array}{c}0.07 * * * \\
(0.001)\end{array}$ & 259,005 \\
\hline $\begin{array}{l}\text { Laundry } \\
\text { Detergents }\end{array}$ & $\begin{array}{c}0.08 * * * \\
(0.003)\end{array}$ & $\begin{array}{c}0.12^{* * *} \\
(0.002)\end{array}$ & $\begin{array}{c}0.12^{* * *} \\
(0.001)\end{array}$ & $3,002,713$ & $\begin{array}{c}0.18^{* * *} \\
(0.005)\end{array}$ & $\begin{array}{c}0.17^{* * * *} \\
(0.005)\end{array}$ & $\begin{array}{c}0.07 * * * \\
(0.001)\end{array}$ & 274,731 \\
\hline Oatmeal & $\begin{array}{c}-0.03^{* * *} \\
(0.005)\end{array}$ & $\begin{array}{c}-0.03^{* * *} \\
(0.005)\end{array}$ & $\begin{array}{c}-0.00^{* * * *} \\
(0.000)\end{array}$ & 898,099 & $\begin{array}{c}-0.05^{* * *} \\
(0.004)\end{array}$ & $\begin{array}{c}0.003 \\
(0.004)\end{array}$ & $\begin{array}{c}-0.03 * * * \\
(0.002)\end{array}$ & 82,938 \\
\hline Paper Towels & $\begin{array}{c}0.15^{* * *} \\
(0.010)\end{array}$ & $\begin{array}{c}0.15^{* * *} \\
(0.010)\end{array}$ & $\begin{array}{c}0.06 * * * \\
(0.001)\end{array}$ & 807,388 & $\begin{array}{c}0.03 * * * \\
(0.005)\end{array}$ & $\begin{array}{l}0.01^{* *} \\
(0.005)\end{array}$ & $\begin{array}{l}0.01 * * * \\
(0.002)\end{array}$ & 133,369 \\
\hline $\begin{array}{l}\text { Refrigerated } \\
\text { Juices }\end{array}$ & $\begin{array}{c}0.07 * * * \\
(0.005)\end{array}$ & $\begin{array}{c}0.08 * * * \\
(0.005)\end{array}$ & $\begin{array}{c}0.07 * * * \\
(0.001)\end{array}$ & $1,702,858$ & $\begin{array}{c}0.01 * * * \\
(0.002)\end{array}$ & $\begin{array}{c}0.01 * * * \\
(0.002)\end{array}$ & $\begin{array}{c}0.01 * * * \\
(0.001)\end{array}$ & 463,897 \\
\hline Soft Drinks & $\begin{array}{c}0.76^{* * * *} \\
(0.011)\end{array}$ & $\begin{array}{c}0.34 * * * \\
(0.007)\end{array}$ & $\begin{array}{c}0.30 * * * \\
(0.001)\end{array}$ & $8,516,259$ & $\begin{array}{c}0.56^{* * * *} \\
(0.007)\end{array}$ & $\begin{array}{c}0.14^{* * * *} \\
(0.003)\end{array}$ & $\begin{array}{c}0.20 * * * \\
(0.001)\end{array}$ & $2,225,483$ \\
\hline Shampoos & $\begin{array}{c}0.15^{* * *} \\
(0.013)\end{array}$ & $\begin{array}{c}0.11^{* * *} \\
(0.010)\end{array}$ & $\begin{array}{c}0.10^{* * *} \\
(0.000)\end{array}$ & $4,416,767$ & $\begin{array}{c}-0.08^{* * *} \\
(0.005)\end{array}$ & $\begin{array}{c}-0.05^{* * *} \\
(0.003)\end{array}$ & $\begin{array}{c}-0.00 \\
(0.001)\end{array}$ & 249,798 \\
\hline Snack Crackers & $\begin{array}{l}0.01 * * \\
(0.006)\end{array}$ & $\begin{array}{c}0.02 * * * \\
(0.006)\end{array}$ & $\begin{array}{c}0.03^{* * *} \\
(0.000)\end{array}$ & $3,019,467$ & $\begin{array}{c}-0.03 * * * \\
(0.001)\end{array}$ & $\begin{array}{c}-0.03 * * * \\
(0.001)\end{array}$ & $\begin{array}{c}-0.04^{* * *} \\
(0.001)\end{array}$ & 468,097 \\
\hline Soaps & $\begin{array}{c}0.16^{* * *} \\
(0.004)\end{array}$ & $\begin{array}{c}0.15^{* * *} \\
(0.004)\end{array}$ & $\begin{array}{c}0.12^{* * *} \\
(0.001)\end{array}$ & $1,662,739$ & $\begin{array}{c}0.07^{* * *} \\
(0.003)\end{array}$ & $\begin{array}{c}0.07 * * * \\
(0.003)\end{array}$ & $\begin{array}{c}0.01 * * * \\
(0.001)\end{array}$ & 172,457 \\
\hline Toothbrushes & $\begin{array}{c}-0.04 * * * \\
(0.004)\end{array}$ & $\begin{array}{c}-0.02^{* * *} \\
(0.005)\end{array}$ & $\begin{array}{c}0.02^{* * *} \\
(0.000)\end{array}$ & $1,662,831$ & $\begin{array}{l}0.01 * * \\
(0.005)\end{array}$ & $\begin{array}{c}0.00 \\
(0.005)\end{array}$ & $\begin{array}{c}-0.07 * * * \\
(0.001)\end{array}$ & 109,327 \\
\hline
\end{tabular}




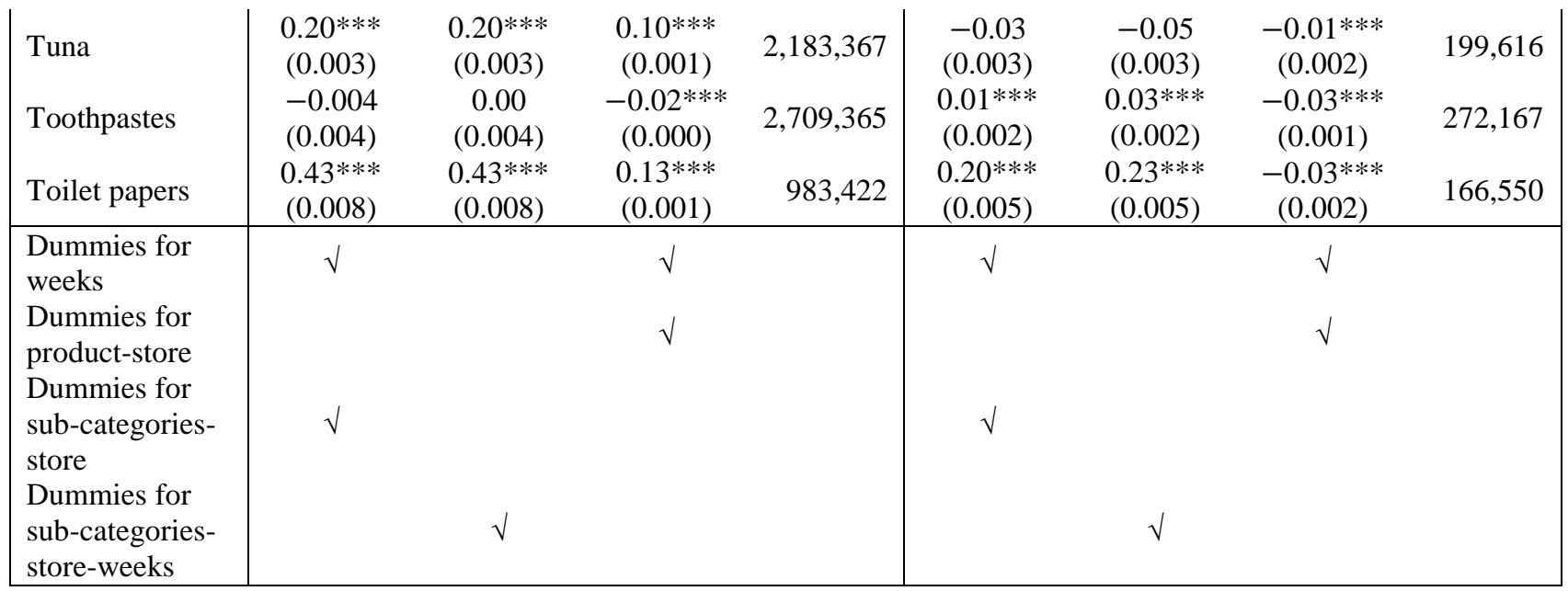

Notes

In the table, we report the coefficient estimates of a 9-ending dummy in a number of OLS regressions with fixed effects, where the dependent variable is the log of the prices. In columns (1)-(3), we report the results when we estimate the regression using data on regular prices only. In columns (4)-(6), we report the results when we estimate the regression using data on sale prices only. We identify sale prices using "Sale Filter A" of Nakamura and Steinsson (2008). In columns (1) and (4), the regression includes controls for weeks and for subcategories-store. In columns (2) and (5), the regression includes controls for subcategories-stores-weeks. In columns (3) and (6), the regression includes dummies for weeks and for product-store. In parentheses we report robust standard errors, clustered at the store level. ${ }^{*} p<10 \%$, $* * p<5 \%$, *** $p$ $<1 \%$. 
Figure 1. Frequency Distribution of the Last Digit of the Retail Prices at Dominick's, September 14, 1989-May 8, 1997

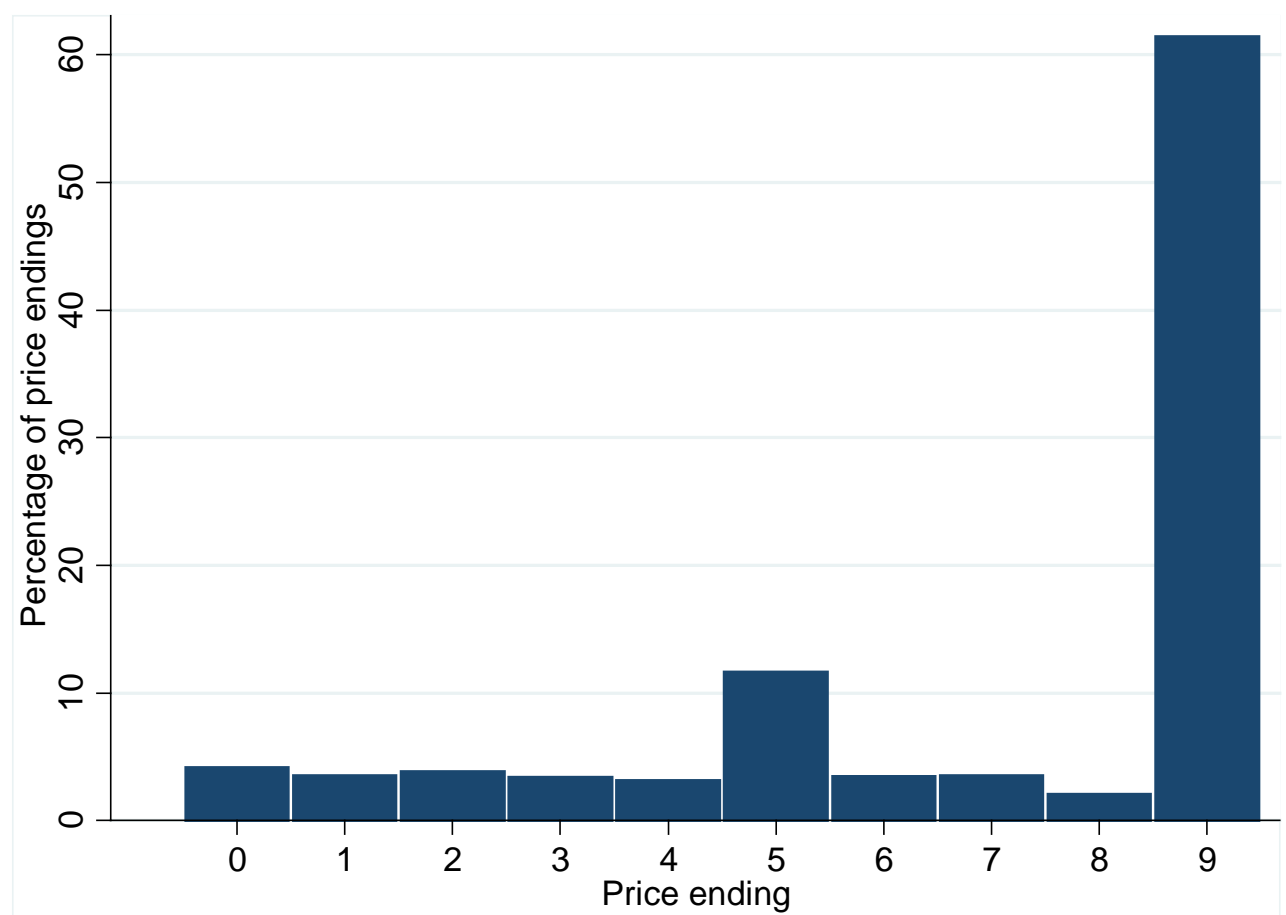

Notes

The figures in the table are based on all price data of Dominick's, at 93 stores for 400 weeks, from September 14, 1989 to May 8, 1997 
Figure 2. Frequency Distribution of the Last Digit of the Retail Prices at Dominick's, by Product Category, September 14, 1989-May 8, 1997
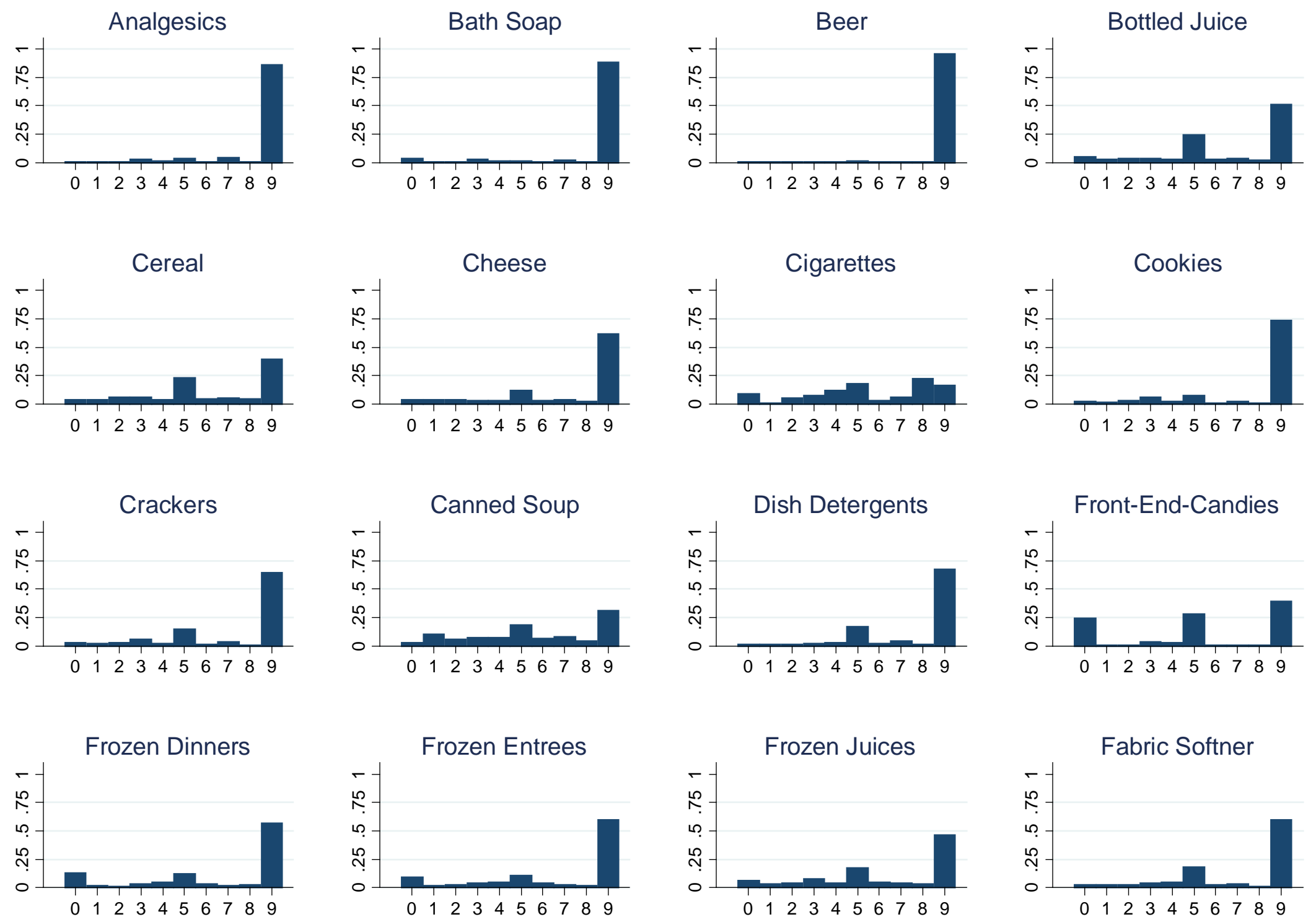
Figure 2. Frequency Distribution of the Last Digit of the Retail Prices at Dominick's, by Product Categories, September 14, 1989-May 8, 1997 (Cont.)
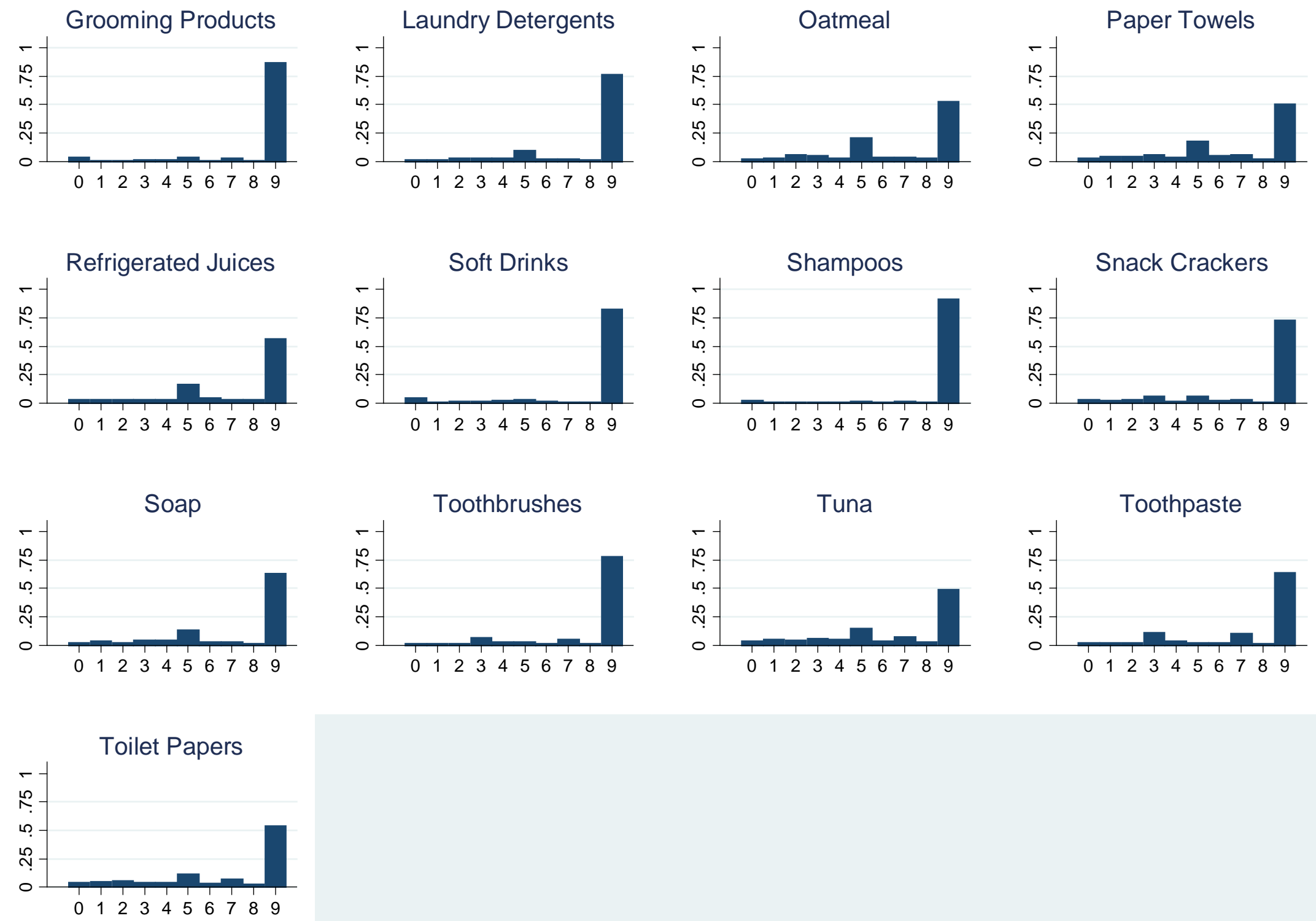
Figure 3. Frequency Distribution of the Percentage Differences between the Average 9-Ending and Non 9-Ending Prices, by Product Categories at the Product-Store Level, Dominick’s, September 14, 1989-May 8, 1997
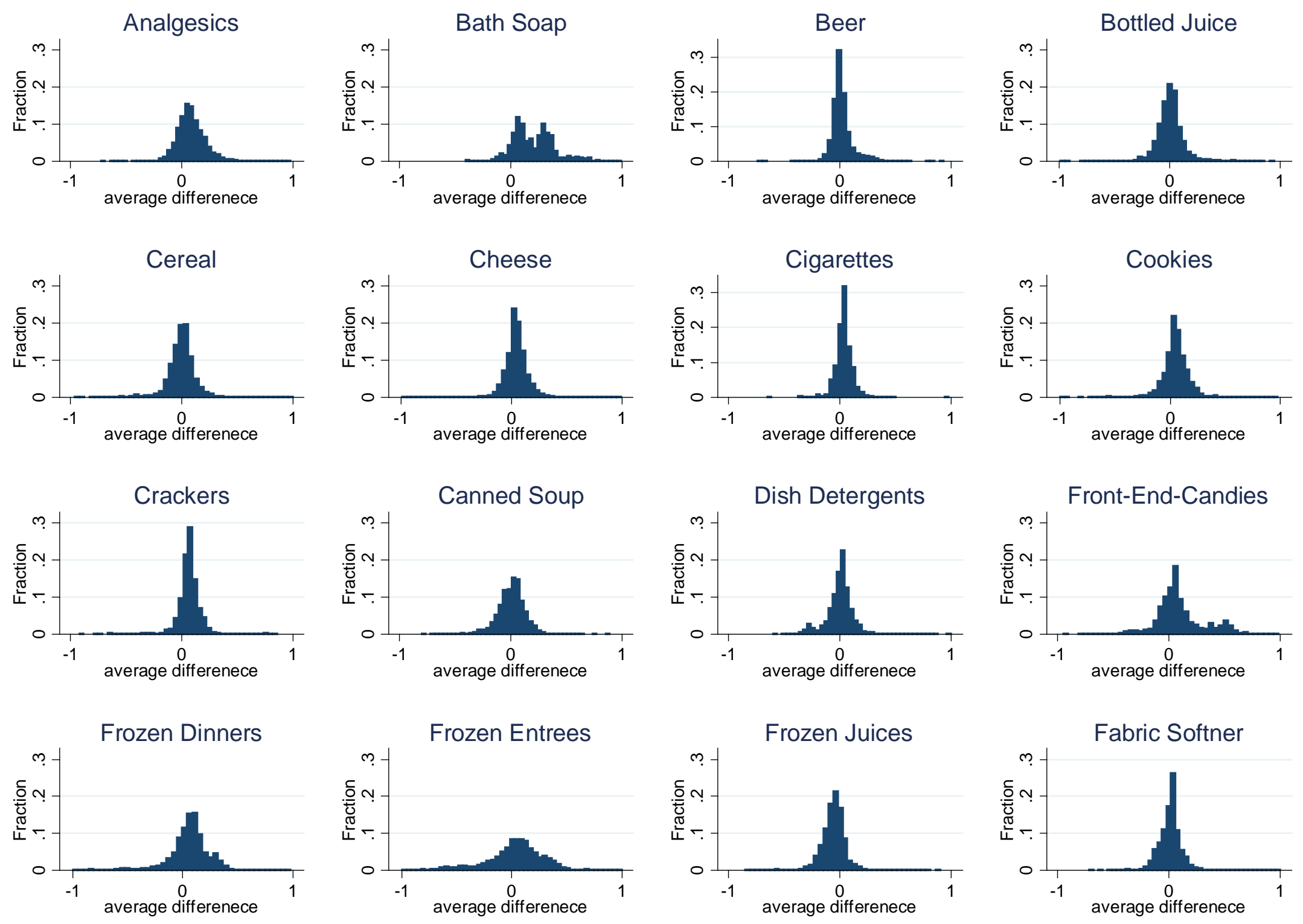
Figure 3. Frequency Distribution of the Percentage Differences between the Average 9-Ending and Non 9-Ending Prices, by Product Categories at the Product-Store Level, Dominick’s, September 14, 1989-May 8, 1997 (Cont.)
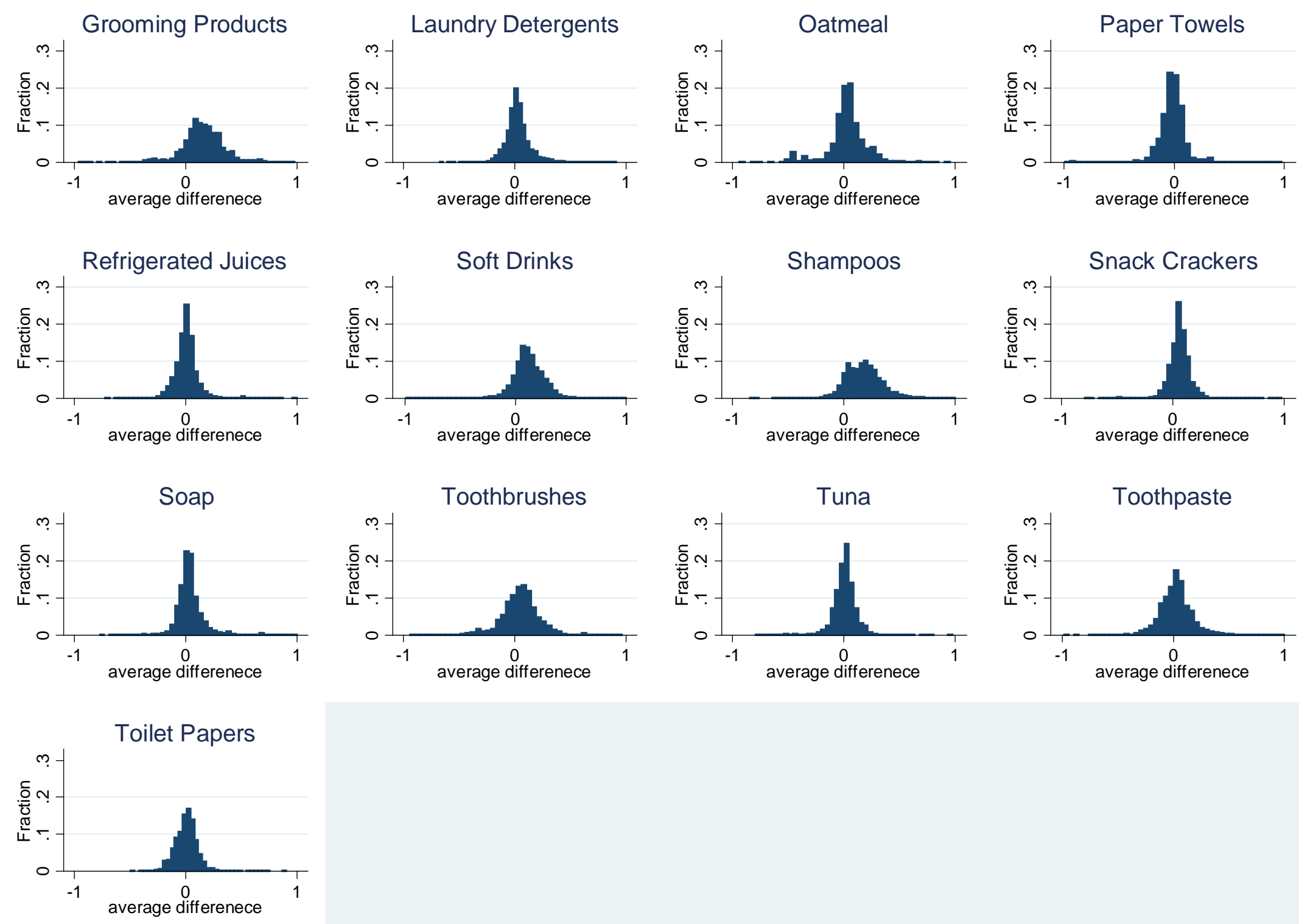